\title{
Perspective on the Therapeutic Applications of Algal Polysaccharides
}

\author{
Sonal Nigam ${ }^{1} \cdot$ Rachana Singh $^{2} \cdot$ Sheetal Kaushik Bhardwaj ${ }^{3} \cdot$ Rokkayya Sami $^{4} \cdot$ Maria P. Nikolova $^{5}$. \\ Murthy Chavali ${ }^{6} \cdot$ Surbhi Sinha ${ }^{2}$ (I)
}

Accepted: 3 July 2021 / Published online: 20 July 2021

(c) The Author(s), under exclusive licence to Springer Science+Business Media, LLC, part of Springer Nature 2021

\begin{abstract}
Algae are an enormous source of polysaccharides and have gained much interest in human flourishing as organic drugs. Algal polysaccharides have aroused interest in the health sector owing to the various bioactivities namely anticancer, antiviral, immunoregulation, antidiabetic and antioxidant effects. The research community has comprehensively described the importance of algal polysaccharides regarding their extraction, purification, and potential use in various sectors. However, regardless of all the intriguing properties and potency in the health sector, these algal polysaccharides deserve detailed investigation. Hence, the present review emphasizes extensively on the previous and latest developments in the extraction, purification, structural properties and therapeutic bioactivities of algal polysaccharides to upgrade the knowledge for further advancement in this area of research. Moreover, the review also addresses the challenges, prospective research gaps and future perspective. We believe this review can provide a boost to upgrade the traditional methods of algal polysaccharide production for the development of efficacious drugs that will promote human welfare.
\end{abstract}

\section{Graphic Abstract}

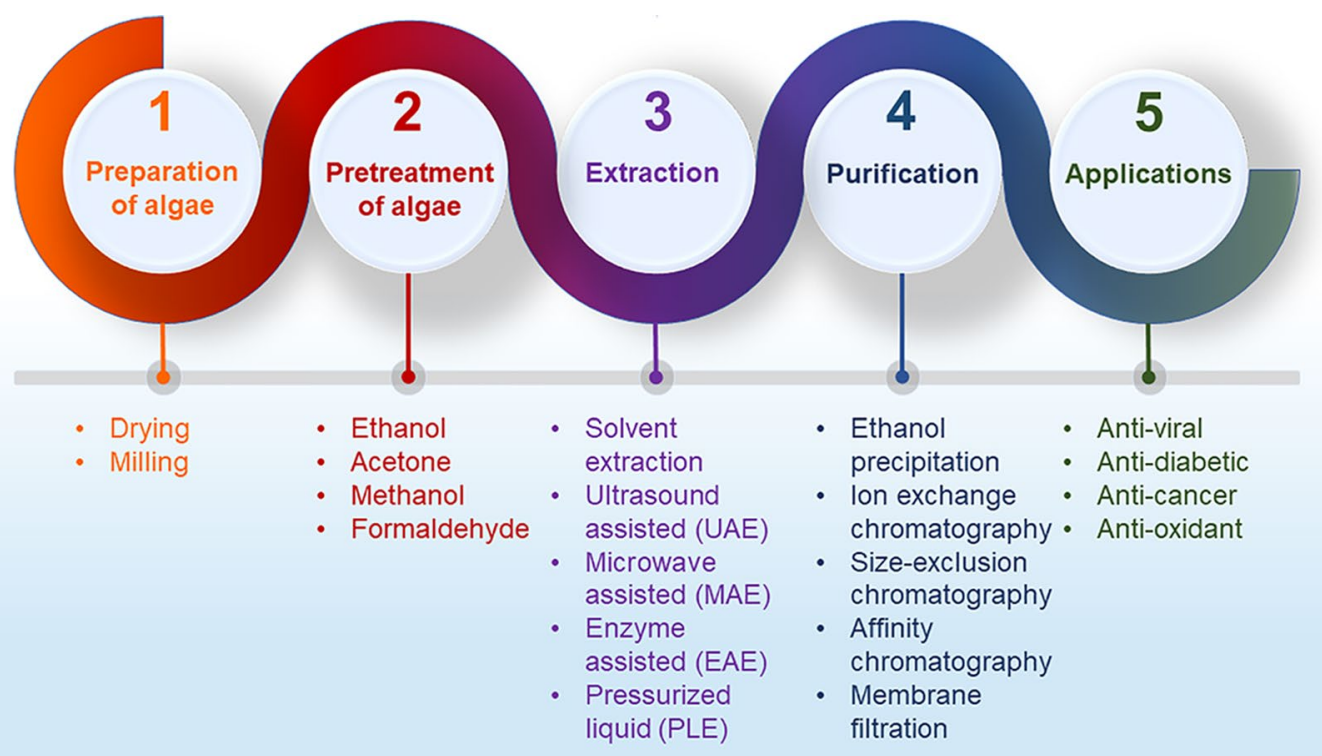

Keywords Algae $\cdot$ Polysaccharide $\cdot$ Extraction $\cdot$ Purification $\cdot$ Bioactivity $\cdot$ Challenges

Surbhi Sinha

ssinha2@amity.edu

Extended author information available on the last page of the article 


\section{Introduction}

Algae are considered the largest and the most propitious natural resources for the next generation biorefineries. It is included in the polyphyletic group and comprises organisms varying from unicellular microalgae (e.g., Chlorella) to multicellular macroalgae (e.g., Kelps). These algae lack vascular tissues and are categorized as photosynthetic eukaryotic organisms [1].

Currently, the global market for algae is approximately U.S. $\$ 782.9$ million which is expected to reach nearly U.S. $\$ 1.2$ billion by 2027 [2]. Algal cultivation is encouraged worldwide to meet the requirement of renewable biomass source for industrial implementation and also for the production of sustainable feed and energy. The everincreasing inclination towards algae is due to their easy availability and very few side effects [3]. Moreover, there are numerous benefits associated with algae such as no additional freshwater or fertilizer is required for its cultivation, the produce is very high as compared to land plants and even its production method does not occupy any extra agricultural space or terrestrial land [4].

These algae contain large quantities of polysaccharides as their main cell wall constituent that imparts them flexibility and strength to sustain strong waves and uphold ionic equilibrium [5]. Polysaccharides are biomacromolecules, composed of about 30-50 monosaccharide units joined together by a glycosidic bond, together with many complex sugars [6]. The polymeric chain resulting in polysaccharide can either be linear or branched, linked to different substituents viz. amino acids, sulphates or acyl groups [7]. At first, used by the industries as thickening agents, polysaccharides have now garnered considerable attention by the researchers due to their various therapeutic bioactivities like antibacterial, antiviral, anticancer, radioprotective, antioxidant, antiinflammatory and immunomodulatory effects [8].

Since the demand for polysaccharide is rising rapidly, researchers worldwide are trying to utilize these natural algal biomasses to fulfil the requirements. The exploitation of these excellent natural resources for the extraction of polysaccharides not only supports the agenda of going green but also makes the entire process recyclable and renewable creating a sustainable environment. Furthermore, the polysaccharides procured from algae are innocuous, readily available in the environment, safe, biodegradable, biocompatible and inexpensive [9]. Polysaccharides like fucoidan, carrageenan, alginates, laminarin and ulvan have been successfully extracted from algae and utilized as anti-inflammatory, anticancer, antioxidant, anticoagulant, immunostimulatory and antiproliferative agents [10-14].

Despite the fact a considerable amount of research has been reported on the potency of these algal polysaccharides in the health sector, their commercial products are still scanty in the market. Thus, we should try increasing our knowledge and understanding of algal polysaccharides, so that high value-added implementation of these algal polysaccharides could bring possibilities for establishing a blooming industry. Moreover, the polysaccharide yield of algae is generally low. Therefore, the scientific community from around the globe should consider developing the methods for extracting algal polysaccharides that would improve the extraction yield, are completely green, socially acceptable, less toxic and commercially viable to attain a sustainable environment.

Thus, to procure and purify algal polysaccharides with maximum therapeutic bioactivities, ideal algal strain together with the appropriate extraction strategies and good manufacturing practices should be adopted. Therefore, the present review provides a comprehensive overview of the extraction, purification, characterization and therapeutic activities of algal polysaccharides. Extensive studies on the conventional and advanced extraction techniques are reviewed together with a critical discussion on their merits and demerits. The latest information on the bioactivities of algal polysaccharides together with their mechanism is also described. The article identifies the challenges; research gaps and future perspective in this particular area of research that would help enhance the knowledge to meet the bioeconomic issues and opportunities.

\section{Extraction of Polysaccharides from Algae}

The entire procedure for the extraction of algal polysaccharides encompasses a series of steps namely, preparation and pre-treatment of algae followed by extraction and purification methods to procure the required polysaccharide. Subsequently, the isolated polysaccharides are probed for their bioactivities and prospective industrial applications.

\section{Preparation of Algal Biomass Before Extraction}

This is the basic step of polysaccharide extraction. The procedure is initiated by cleaning the algae using distilled or seawater, to remove the soil particles and epiphytes associated with algae. The process is followed by either air drying, freeze-drying or oven-drying the biomass [15, 16]. The dried biomass then undergoes the process of milling to generate fine particles with a high surface to volume ratio consequently increasing its interaction with solvent and enhancing the efficiency of extraction. A novel method was patented as an alternative to the drying method [17] which were found to be highly efficient towards obtaining 
laminarin and fucoidan from living, harvested macroalgal biomass by exudate method, wherein, the polysaccharides, were procured from the harvested algal exudate solution.

\section{Pre-treatment of the Biomass Before Extraction}

Various types of pre-treatments are provided to the dried algal biomass to eliminate proteins, lipids, pigments, phenols, mannitol and other low molecular weight compounds that remain bound to the polysaccharide. Thus, a myriad of solvents and their mixtures with varied polarities that do not induce any structural alteration in the polysaccharide are utilized. Pre-treatment of algal biomass with formaldehyde is the most favourable method for alginate extraction [18-20]. January et al. [21] used methanol, chloroform and water in the ratio of $4: 2: 1(\mathrm{v} / \mathrm{v} / \mathrm{v})$ for fucoidan extraction. Similarly, for laminarin extraction from Gongolaria barbata (formerly known as Cystoseira barbata), Sellimi et al. [22] treated the algal biomass first with the solvent mixture of acetone and methanol in the ratio of 7:3 (v/v), followed by chloroform treatment for $24 \mathrm{~h}$ at $30{ }^{\circ} \mathrm{C}$. Due to the toxicity and negative environmental impact of chloroform, its usage is restricted and new alternative pre-treatment methods, free of chloroform are being recommended. Sahera et al. [23] pre-treated Polycladia myrica (formerly known as Cystoseira myrica) using petroleum ether and acetone before polysaccharide extraction. Similarly, Abid et al. [24] removed lipophilic pigments and low molecular weight proteins from Dictyopteris polypodioides (formerly known as Dictyopteris membranacea) and Padina pavonica using petroleum ether and acetone. Additionally, many other possibilities with solvents: acetone and ethanol at varying temperatures have been discovered for the pretreatment process [25]. Recently, Huang et al. [26] have reported a novel pre-treatment method for extraction of fucoidan that includes compressional puffing-hydrothermal process, which allows the heating of algae at high atmospheric pressures viz. 140, 180 and $220{ }^{\circ} \mathrm{C}$ ensuing a rapid drop of pressure in a container carrying superhot water, leading to variations in the cell structure of algae. At a laboratory scale, low molecular weight proteins are usually removed using Sevag reagent, but due to the presence of chloroform in it, enzymatic hydrolysis under mild conditions are preferred [27]. Mostly, phenols are eliminated from algae by bleaching with hydrogen peroxide but its high concentration can decompose polysaccharide, thereby decreasing its molecular weight and extraction yield [28, 29]. Thus, recently, organic solvents and microporous resins are being utilized for phenol removal $[30,31]$.

\section{Conventional Extraction Techniques for Algal Polysaccharides}

Extraction is the prime step in isolating polysaccharides from the algae. Thus, to extract the polysaccharides from the cell walls of various species of algal biomass, some explicit techniques have been utilized to reach the conditions where the desired compound is drawn out easily. The conventional method of algal polysaccharide extraction mainly uses solvents like hot water, acids, alkalis or a combination of these as an extraction medium. The process involves administering the pre-treated algal biomass to different solvents for definite hours at different temperatures to obtain polysaccharides with minimum impurities [32]. Also, the produce of polysaccharide after extraction using these solvents is species dependent. For example, a $43.57 \%(\mathrm{w} / \mathrm{w})$ of total polysaccharide comprising fucoidan, alginate and laminarin were extracted from algae Durvillaea potatorum using $0.05 \mathrm{M} \mathrm{HCL}$ at $60{ }^{\circ} \mathrm{C}$ for $3 \mathrm{~h}$ [33]. Chi et al. [34] reported extraction of $11.27 \mathrm{~g}$ of rhamnan rich sulphated polysaccharide ulvan from Ulva clathrata using hot water. Furthermore, 19\% (w/w) fucoidan was recovered from Sargassum sp. utilizing a hot buffer as an extraction medium at $60{ }^{\circ} \mathrm{C}, \mathrm{pH} 4$ and buffer: alga ratio of $10 \mathrm{ml} / \mathrm{g}$ [35]. Carrageenan yield of $32.95 \pm 1.43 \%$ from Kappaphycus alvarezii have been reported by Meinita et al. [36] using an alkaline method $\left(60 \% \mathrm{KOH}\right.$ solution) at $80{ }^{\circ} \mathrm{C}$ for $3 \mathrm{~h}$.

Although conventional methods produce a certain amount of polysaccharide from algal biomass a couple of constraints such as lengthy extraction time with little production of polysaccharides, requirement of high purity solvents accompanied by their excess evaporation, manual handling, problems in the management of heat-labile compounds and environmental threat due to contaminating organic compounds restrict their use and consequently make these methods less feasible [37]. Thus, to combat the flip side of these conventional techniques, some innovative and propitious unconventional extraction methods have been introduced. Mostly, these non-conventional methods abide by the standards defined by the U.S Environmental Protection Agency (EPA) and hence are believed to be "green" and eco-friendly in nature. Significant benefits associated with these non-conventional techniques include the reduced application of chemicals, environment-friendly processing conditions, low utilization of water, highly energy-efficient, less use of solvents, cost-effectiveness, higher efficacy, decreased generation of by-products and utilization of green solvents such as deep eutectic solvents. Deep eutectic solvents are liquids (at a temperature lower than $100{ }^{\circ} \mathrm{C}$ ), consisting of two or more cheap and impervious substances, linked through 
hydrogen bonds, forming a eutectic mixture having a melting point less than that of individual constituent [38, 39]. These solvents offer benefits like inconsiderable vapour pressure, excellent thermal characters, broad liquid range, good solubility, low cost, eco-friendly nature and exceptional recycling property [40]. The new unconventional techniques for the extraction of algal polysaccharides are further detailed in the succeeding sections.

\section{Advanced Extraction Methodologies for Algal Polysaccharides}

\section{Supercritical Fluid Extraction Method}

Supercritical fluid extraction is a method in which the separation of the components takes place from the matrix by using supercritical fluids as an extracting solvent [41]. A supercritical fluid is any homogenous fluid formed at a temperature and pressure above its critical point, where liquid and gas phases become indistinguishable [42]. It can effuse through solids like a gas and dissolve materials like a liquid. The most commonly used supercritical solvent for extraction is carbon dioxide owing to its heat transfer and thermodynamics characteristics, non-hazardous nature, chemical inertness, low cost, non-flammability and eco-friendly behaviour [43-45]. The supercritical fluid extraction technique was first used in 1969 by Zosel for extracting valuable compounds at an industrial scale [46]. Since then, a lot of compounds like lipids, fatty acids, antioxidants have been extracted using this supercritical fluid extraction method [47] but very few reports on the extraction of algal polysaccharides utilizing the same technique have been published $[48,49]$. This can be due to some challenges associated with this method namely, high cost, as the requirement of high pressure, increases the overall budget as compared to the conventional liquid extraction method and the non-polar nature of the carbon dioxide makes it inappropriate as a solvent for polar solutes $[50,51]$. Though the method has some drawbacks; advantages like reduced product contamination, great selective extraction, the requirement of less time for processing, faster diffusivities of supercritical fluid and its absolute separation from the analyte [52, 53] establishes it as a suitable method for the extraction of algal polysaccharides and should be explored extensively by the scientific community from all over the world. The working scheme of the supercritical fluid extraction method is represented in Fig. 1 that comprises a $\mathrm{CO}_{2}$ reservoir, $\mathrm{CO}_{2}$ pump, co-solvent reservoir, co-solvent pump, extraction cell; back pressure valve and collector. The system of supercritical fluid extraction is established on (i) dynamic mode (ii) static mode (iii) a combination of both.

\section{Ultrasound-Assisted Extraction}

Ultrasound-assisted extraction is believed to be one of the highly sophisticated, useful and functional methods for the extraction of polysaccharides from algae owing to their low cost, easy handling, user-friendliness, rapid rate of extraction, little usage of solvents and higher plausibility

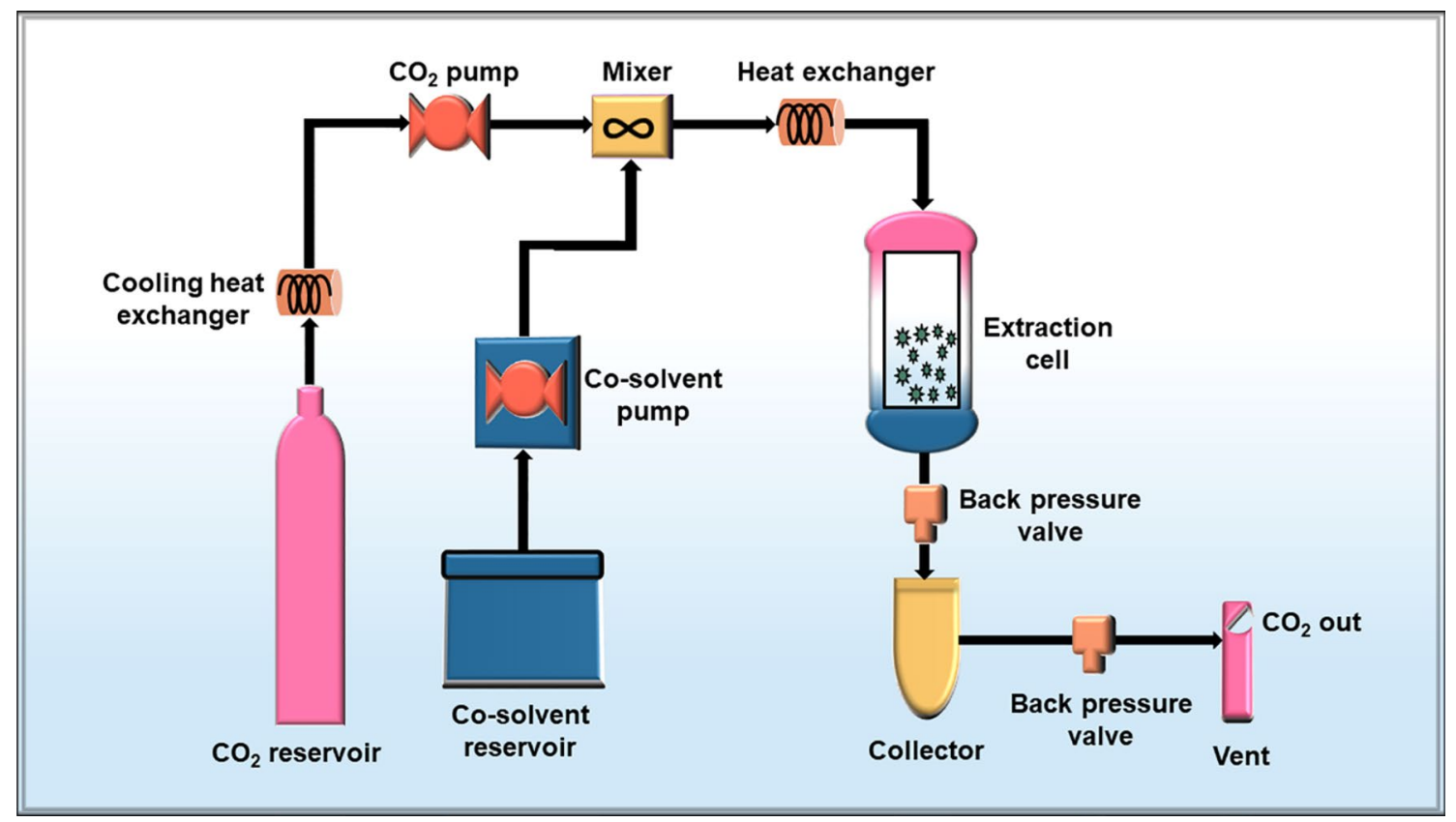

Fig. 1 Schematic layout of the working scheme for the supercritical fluid extraction method 
of upgrading to industrial level $[54,55]$. Moreover, it can be amalgamated with other advanced technologies like an enzyme or microwave-assisted extraction, supercritical fluid extraction methods for enhanced recovery of polysaccharides [56, 57]. Ultrasound-assisted extraction is the process where ultrasound frequencies of more than $20 \mathrm{kHz}$ are employed to wobble the fine particles in the sample for the extraction of various polysaccharides from algae. Customarily, the extraction process is mediated by the movement of ultrasonic waves that creates high energy cavitation bubbles containing solvent vapour. Eventually, these cavitations collapse and ultrasonic waves are metamorphosed into mechanical energy. This mechanical energy then ruptures the cell wall and reduces the particle size. As the cell wall ruptures, the polysaccharides are released out [58]. Ultrasound technology together with hydrothermal assisted extraction and thermal treatment yielded $2971.7 \pm 61.9 \mathrm{mg}$ fucose $/ 100 \mathrm{~g}$ dried macroalgal residue from Ascophyllum nodosum [59]. Santagata et al. [60] described the ultrasound-assisted extraction of alginate from Sargassum. Hariharasubramanian et al. [61] stated improved yield of polysaccharide $(24.8 \% \pm 1.28 \%)$ by using a pulsed ultrasonic treatment in comparison to conventional hot water extraction that yielded only $11.08 \pm 0.78 \%$ polysaccharide from Sargassum muticum. Additionally, fucoidan was also extracted from Sargassum muticum by ultrasonication at $25^{\circ} \mathrm{C}$ for 5-30 min [62]. The crude fucoidan showed the maximum sulphate content of $39.54 \pm 0.001 \mathrm{mg}$ sulphate ion/g extract. Hmelkov et al. [63] utilized ultrasound aided extraction of polysaccharide fucoidan from Fucus distichus subsp. evanescens (formerly known as Fucus evanescens). The fraction of the obtained fucoidan showed anticancer activity in vitro towards human colon carcinoma. Recently, ultrasonic-assisted extraction of polysaccharides from Sargassum horneri utilizing deep eutectic solvents was suggested by Nie et al. [64]. Results reported a polysaccharide yield of $11.31 \%$ in 30 min with significant antioxidant activities.

The efficacy of ultrasound-assisted extraction of polysaccharides is determined by multiple variables like time, temperature, ultrasonic power and ratio of solvent to solids. Thus, it becomes imperative to optimize these parameters to attain the maximum yield of polysaccharide. Garcia-Vaquero et al. [65] reported extraction of fucose $(1060.7 \pm 70.6 \mathrm{mg} / 100 \mathrm{~g}$ dried seaweed) and total glucans $(968.6 \pm 13.3 \mathrm{mg} / 100 \mathrm{~g} \mathrm{ds})$ from Laminaria digitata at the optimized conditions $\left(76^{\circ} \mathrm{C}, 10 \mathrm{~min}\right.$ and amplitude of $\left.100 \%\right)$ obtained through response surface methodology. Moreover, Vázquez-Rodríguez et al. [66] utilized the optimum parameters $\left(50^{\circ} \mathrm{C}\right.$, ultrasound power density $3.8 \mathrm{~W} / \mathrm{cl}$, solvent/ seaweed ratio of $30 \mathrm{ml} / \mathrm{g}$ and $32.33 \%$ ethanol concentration) obtained through Box-Behnken design model that yielded $23 \%(\mathrm{w} / \mathrm{w})$ polysaccharides using ultrasonic extraction from a brown seaweed Silvetia compressa. Response surface methodology was also applied by Rahimi et al. [67] to optimize the parameters for ultrasound augmented extraction of ulvan from Ulva intestinalis. At optimum conditions, $8.30 \%$ of ulvan was obtained that exhibited reducing and 2,2-diphenyl picrylhydrazyl radical scavenging capability. A polysaccharide yield of $13.583 \pm 0.51 \%$, was obtained from Arthrospira platensis (formerly known as Spirulina platensis) by Kurd and Samavati [68] at optimum conditions of $25 \mathrm{~min}, 85^{\circ} \mathrm{C}, 90 \mathrm{~W}$ ultrasonic power and ratio of water to raw material $20 \mathrm{ml} / \mathrm{g}$ determined by response surface methodology. The extracted polysaccharide showed anticancer activity. The schematic workflow of ultrasound-mediated extraction is shown in Fig. 2. It consists of a sonicator probe, hot plate and ultrasonicator generator to maintain temperature and power, respectively.

\section{Pressurized Liquid Extraction}

Recently, pressurized liquid extraction has been regarded as one of the fastest, safest and easiest approaches for the extraction of algal polysaccharides [69]. It was first introduced by Richter et al. [70] as a new technique to extract various biochemical compounds by coalescence of elevated temperature and pressure with liquid solvents. The temperature and pressure conditions employed in the pressurized liquid extraction method are between $50-200{ }^{\circ} \mathrm{C}$ and 3.5-20 MPa, respectively [71]. Due to its broad range of functionality, it is also diversely designated as pressurized solvent extraction, pressurized fluid extraction, accelerated solvent extraction or subcritical water extraction [71, 72]. The various benefits associated with pressurized liquid extraction are: it is faster, easier to use, automated, requires minimal solvent, saves time and money, increases productivity, improves reproducibility and significantly minimizes exposure to solvents [73]. These advantages completely satisfy the agenda of achieving a green and sustainable environment. Saravana et al. [74] utilized pressurized liquid extraction to extract fucoidan from brown seaweed Saccharina japonica. $8.23 \%$ of crude fucoidan was extracted with a molecular weight ranging between 83.39-183.32 kDa. The obtained fucoidan displayed excellent antioxidant activities. The pressurized liquid extraction approach was utilized as an alternative green approach by Santoyo et al. [75] to extract polysaccharide fractions from edible brown seaweed Himanthalia elongata. The polysaccharide fraction proved effective as an antiviral drug opposite Herpes Simplex Virus Type I. Pressurized liquid extraction of polysaccharides from seaweeds can be performed in both the static and dynamic mode [76-78]. Commercially, a static mode is more frequently utilized to extract polysaccharides than the dynamic mode [79]. The performance of the pressurized liquid extraction method is dependent on diverse parameters viz. pressure, temperature, extraction solvent, several cycles and time [80]. 


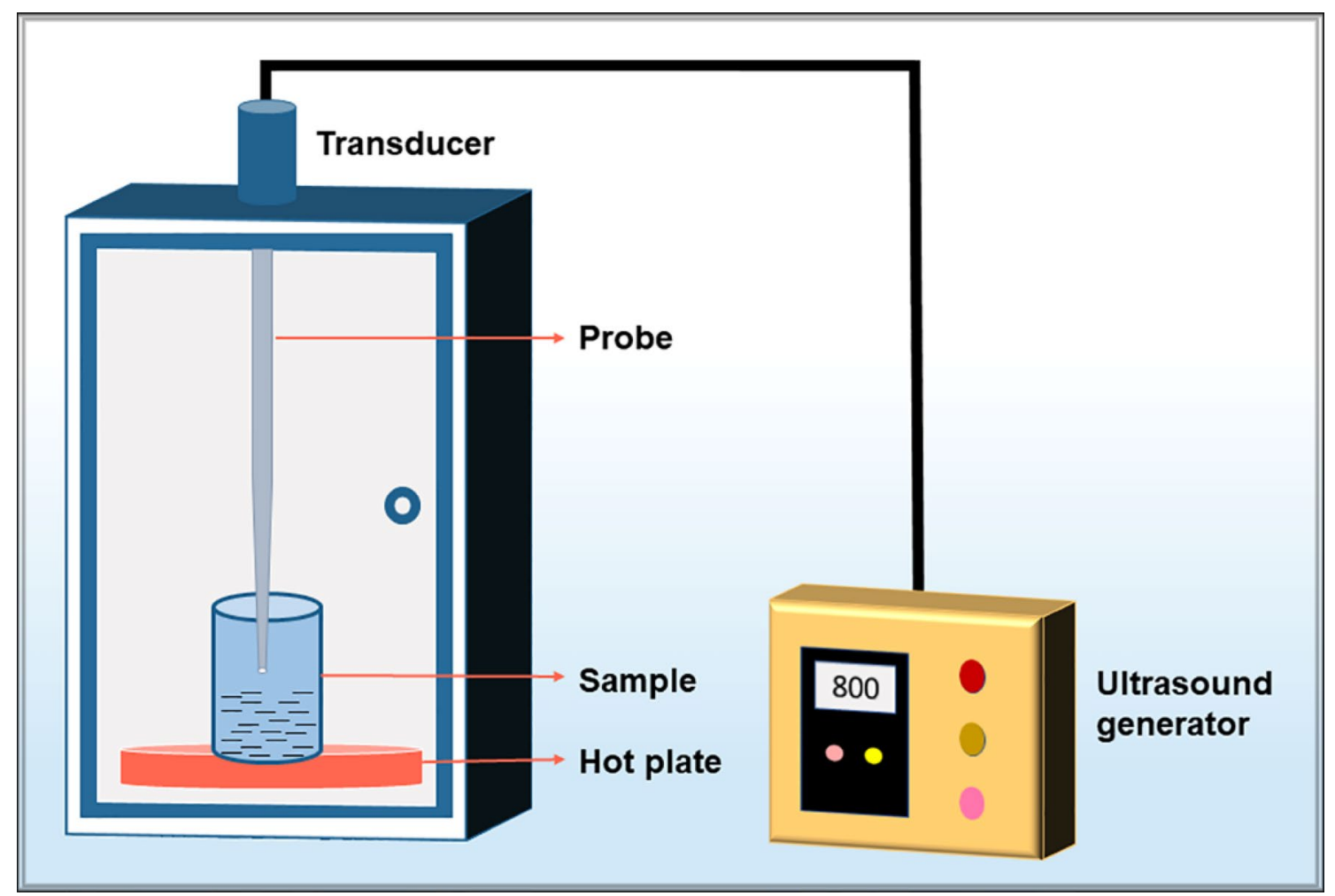

Fig. 2 Schematic layout showing the work flow for ultrasound-assisted extraction method

Each of these parameters can be optimized separately using some experimental designs or statistical software for maximum retrieval of polysaccharides. A schematic depiction of a pressurized liquid extraction system and its workflow is represented in Fig. 3. Generally, the extraction equipment consists of a solvent tank linked to a high-pressure pump. A nitrogen gas tank and solvent tank follow the pressure pump and both are coupled with the oven. Valves regulate the flow of the solvent and nitrogen gas into the extraction unit which is positioned within the oven. The extracted compound is then collected in the collection vial.

\section{Microwave-Assisted Extraction}

Microwave-assisted extraction is another novel technique that has been extensively utilized to obtain high-value biologically active compounds from algae and plants [81, 82]. Apart from being environment friendly, the microwaveassisted extraction method offers some magnificent benefits like simplicity in functionality, less utilization of solvents, short extraction period, improved yield and also obstructs the breakdown of compounds that are readily degraded by heat $[83,84]$. Owing to these advantages, this technique has been widely used by researchers for the procurement of polysaccharides from algae. Cao et al. [85] employed microwaveassisted aqueous two-phase extraction for the simultaneous recovery and separation of polysaccharides from Sargassum pallidum. The results displayed a maximum polysaccharide yield of $0.75 \pm 0.04 \%$ of top phase and $6.81 \pm 0.33 \%$ of bottom phase at $15 \mathrm{~min}, 95^{\circ} \mathrm{C}$, microwave power $830 \mathrm{~W}, 22.0 \%$ ammonium sulphate $(\mathrm{w} / \mathrm{w}), 21.0 \%$ ethanol $(\mathrm{w} / \mathrm{w})$ and the ratio of material to liquid $1: 60(\mathrm{~g} / \mathrm{ml})$. A $29.3 \%$ of carrageenan was extracted from Solieria chordalis utilizing the microwave-assisted extraction method at $10 \mathrm{~min}$ and $90^{\circ} \mathrm{C}$ [86]. The obtained carrageenan exhibited antiviral activity against Herpes simplex virus type I. Similarly, Le et al. [87] also obtained polysaccharide ulvan from Ulva australis (formerly known as Ulva pertusa) employing microwave technology and studied its antioxidant activities. The results established that the ulvan enhanced the activities of oxidative enzymes like catalase and superoxide dismutase. Chen and Xue [88] applied response surface methodology to optimize the microwave-assisted technology for the extraction of polysaccharides from Neoporphyra haitanensis (formerly known as Porphyra haitanensis). They found that $28.98 \mathrm{ml} / \mathrm{g}$ ratios of water to raw material, $77.84 \mathrm{~W}$ microwave power and 14.14 min extraction time yielded $5.02 \%$ polysaccharide. The extracted polysaccharide was determined as a prospective candidate for clinical use in cancer prevention. Ren et al. [89] also recovered $2.84 \pm 0.09 \%$ polysaccharides from Sargassum thunbergii employing microwave extraction method at extraction time $23 \mathrm{~min}$, microwave power $547 \mathrm{~W}$, 


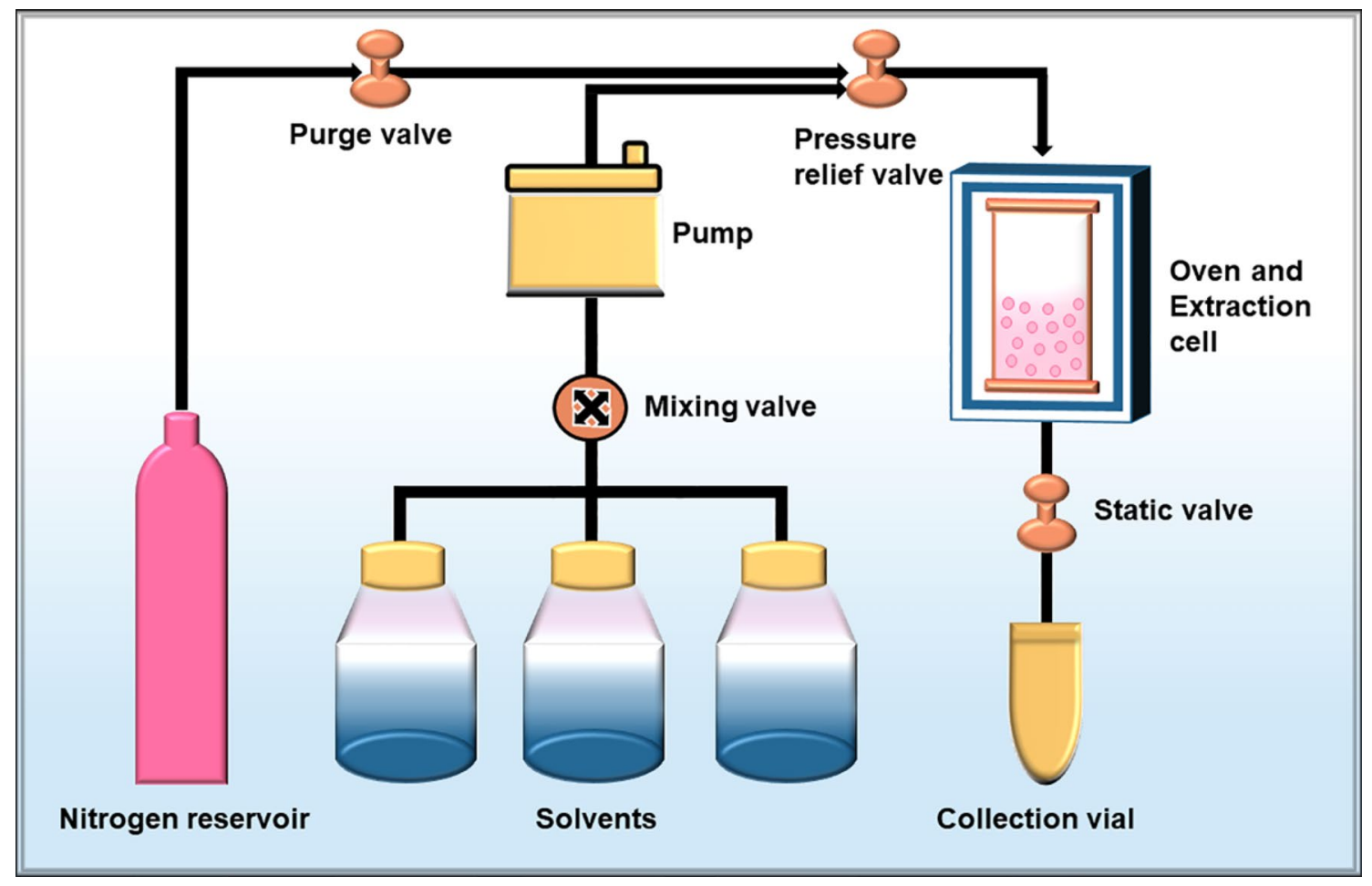

Fig. 3 Diagrammatic representation of the working scheme for the pressurized liquid extraction method

extraction temperature $80^{\circ} \mathrm{C}$, and the ratio of raw material to water $1: 27 \mathrm{~g} / \mathrm{ml}$. Additionally, microwave-assisted extraction using deep eutectic solvent was employed for the extraction of polysaccharides from Fucus vesiculosus. A maximum of $116.33 \mathrm{mg} / \mathrm{g}$ of polysaccharide was procured in $35 \mathrm{~min}$ at $168{ }^{\circ} \mathrm{C}$ with excellent antioxidant and anticancer activities in vitro [90]. Figure 4 shows the schematic diagram of the microwave-assisted extraction of polysaccharides from

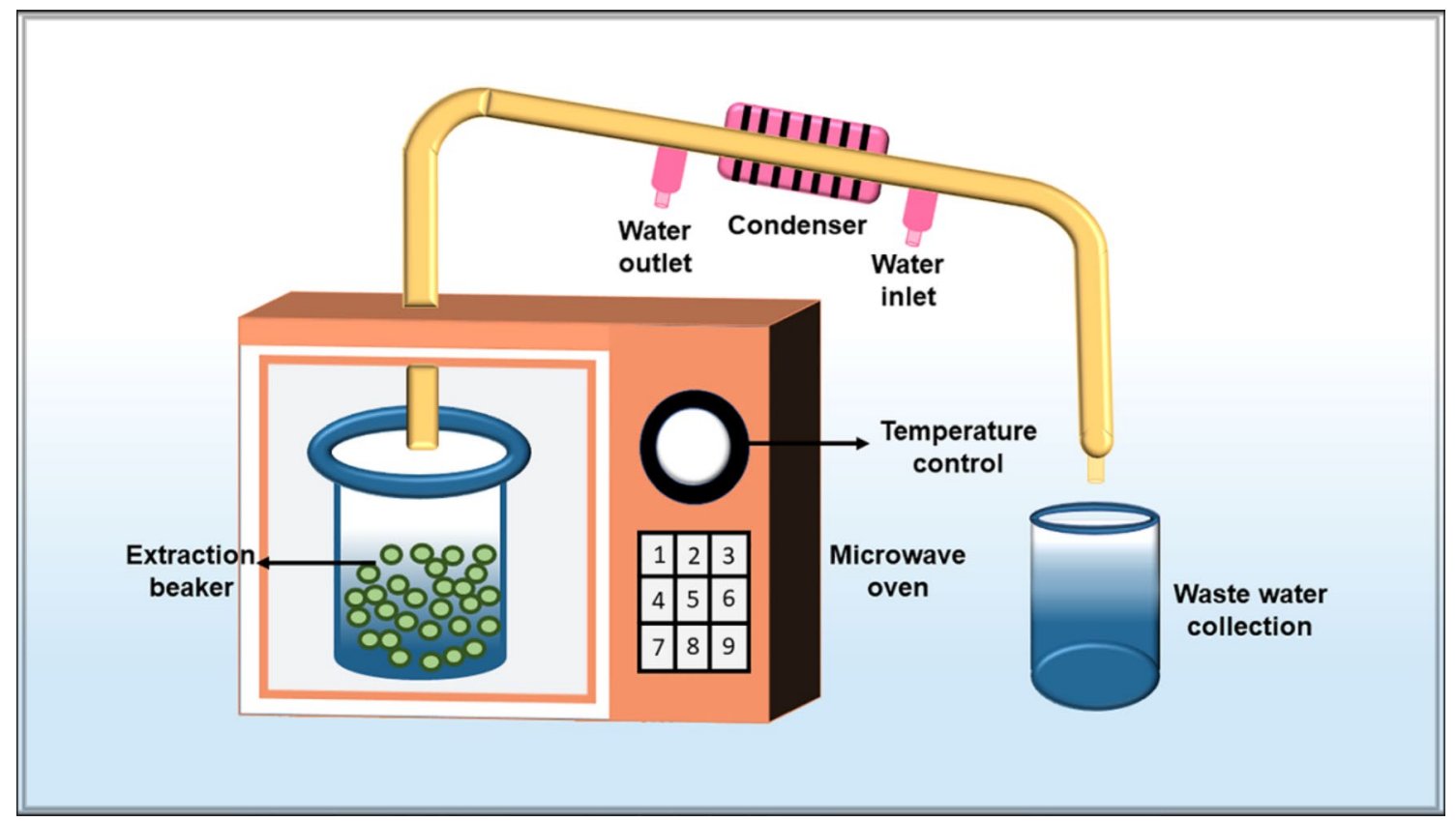

Fig. 4 Schematic representation of the workflow for the microwave-assisted extraction method 
seaweeds. Generally, this technique utilizes microwaves to produce high temperatures and evaporation of intracellular extracts. This results in the degradation of the cell wall and the discharge of intracellular compounds in the medium.

\section{Enzyme Assisted Extraction}

In recent times, enzyme assisted extraction of polysaccharides from algae has gained a lot of attention due to some remarkable benefits namely (a) environmentally safe process (b) high specificity (c) requirement of less energy (d) rapid extraction method (e) high efficiency (f) negligible use of toxic chemicals $(\mathrm{g})$ recyclability $(\mathrm{h})$ easy recovery (i) high productivity (j) high catalytic efficacy [91-93]. Moreover, the enzymes used in the extraction process are innocuous, environment friendly and can be easily utilized in large scale operations [94]. A variety of enzymes such as carrageenases, cellucast, agarose, alcalase, amyloglucosidase and xylanase have been considerably utilized as catalysts in the enzyme extraction process [95, 96]. Alboofetileh et al. [97] extracted fucoidan from brown algae Nizamuddinia zanardinii using flavourzyme, alcalase, viscozyme and cellucast. They reported that maximum polysaccharide was obtained using alcalase enzyme with immune-enhancing and anticancer activities. Fucoidan was also obtained from Fucus distichus subsp. evanescens and Saccharina latissima using the enzymes cellulase and alginate [98]. Fournière et al. [99] extracted crude polysaccharide ulvan from Ulva sp. by combining enzyme assisted extraction with depolymerization. The obtained ulvan exhibited anti-inflammatory activities.
Enzyme assisted extraction method promotes the breakdown of the cell wall, which successively enhances the cell wall permeability, leading to the higher yield of polysaccharides from algae [100]. More precisely, enzyme assisted extraction is dependent on two techniques: (a) enzyme assisted cold pressing (b) enzyme assisted aqueous extraction [101]. Different parameters like $\mathrm{pH}$, temperature, type of enzyme, the concentration of enzyme, surface area, the moisture content are considered pivotal for the extraction process and must be optimized to achieve high productivity [102, 103]. Hammed et al. [104] stated the optimum conditions: extraction stage of 2 , hydrolysis time of $19.5 \mathrm{~h}$ and enzyme concentration of $1.5 \mu \mathrm{l} / \mathrm{ml}$ to produce $25.13 \%$ sulphated polysaccharide. Enzyme assisted extraction methods to extract polysaccharides from algae is established as an environmentally friendly approach as it utilizes water as solvents instead of organic chemicals [100]. Figure 5 depicts the schematic representation of the enzyme assisted extraction of polysaccharides from algae.

\section{Other Ingenious Extraction Methods}

Besides, the extraction methods discussed above, various ingenious methods such as photobleaching, high hydrostatic pressure treatment and reactive extrusion have as well shown encouraging results in the extraction of polysaccharides from seaweeds. For example, Li et al. [105] employed the novel environment-friendly photo-bleaching process for the extraction of agar from Gracilariopsis lemaneiformis (formerly known as Gracilaria

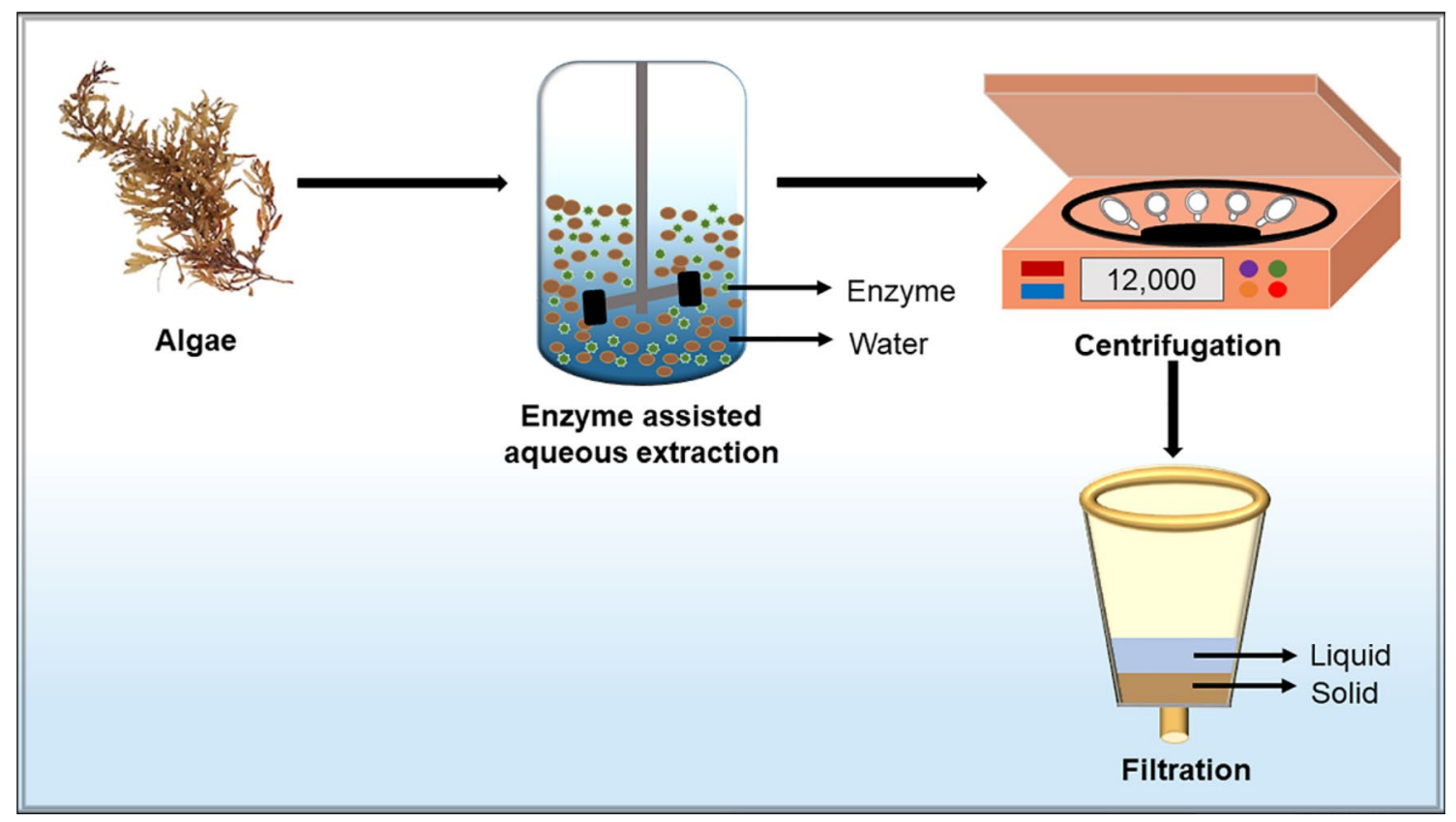

Fig. 5 Graphic representation of the workflow for enzyme assisted extraction method 
lemaneiformis). The obtained photobleached agar showed excellent gel strength of $1913 \mathrm{~g} / \mathrm{cm}^{2}$. Rodrigues et al. [106] used high hydrostatic pressure to obtain polysaccharides from Sargassum muticum. About $40.4 \%$ of polysaccharide was extracted with improved antioxidant activities. Another innovative technique called reactive extrusion was applied for extracting polysaccharide from Laminaria digitata by [107]. The authors reported a high yield of alginate (39\%) in a very less time (5 min) as compared to the alginate concentration (33\%) obtained through the conventional alkaline extraction method in $1 \mathrm{~h}$.

\section{Shortcomings of the Advanced Extraction Methods}

The aforementioned advanced extraction techniques have been described comprehensively by researchers with outstanding advantages compared to the traditional extraction methods. Howbeit, some reports have stated a few limitations of these advanced extraction technologies (Table 1). These shortcomings are primarily because of the high temperature or pressure and plausible degeneration of the extracted polysaccharide. Since, all the novel techniques have their advantages, disadvantages and mechanism for the extraction of polysaccharides, therefore certain factors like nature and purity of the procured polysaccharide, the requirement of solvent and energy during the extraction process should be contemplated before choosing the suitable extraction method. However, the boundaries between these novel extraction techniques are ambiguous and thus a compromise should be made on the technique which has a maximum number of benefits.

\section{Purification and Structural Characterization of Extracted Polysaccharides}

The extracted crude polysaccharide is linked to various unwanted impurities/compounds such as monosaccharides, sulphates, lipids, proteins and pigments. Thus, further separation and purification steps become challenging and hence necessary. The obtained crude polysaccharide is first precipitated with ethanol to remove low molecular weight impurities [118]. Precipitated polysaccharides are then separated by centrifugation [119]. The proteins in the solution are removed using the Sevag reagent or trichloroacetic acid method followed by dialysis against distilled water and drying $[73,120]$. The most preferred method for drying polysaccharide is lyophilization due to its low effect on the structure and activity [121]. Furthermore, to achieve high throughput screening and purification, the resulting polysaccharides are subjected to various column chromatographic techniques. Various models of column chromatography such as Sephacryl S-300, Superdex 200, PL aqua gel-OH, Sepharose CL-6B, DEAE cellulose column, Q-Sepharose fast flow column have been utilized in polysaccharide purification from algae [122, 123]. Apart from the chromatographic techniques, membrane separation technology that includes ultrafiltration, nanofiltration or reverse osmosis have also gained a lot of popularity for the purification of polysaccharides from algae for their successful application in industries $[124,125]$. Table 2 summarizes the different purification techniques along with their merits and demerits. Some of the algal polysaccharides purified using different techniques are compiled in Table 3 together with their experimental conditions.

Table 1 Demerits of various green extraction technologies

\begin{tabular}{|c|c|c|}
\hline Extraction techniques & Disadvantages & References \\
\hline Supercritical extraction technique & High cost, inappropriate for polar solutes, high power consumption & [108] \\
\hline Ultrasound-assisted extraction & $\begin{array}{l}\text { Degradation of compounds may occur at high frequency and long processing time, extra filtra- } \\
\text { tion step may be required, the noise level is high, mixing is not homogenous, destruction of } \\
\text { seaweed can occur, high temperature can negatively affect the process, a suitable probe is } \\
\text { needed to have homogenous sonication intensity }\end{array}$ & {$[109,110]$} \\
\hline Pressurized liquid extraction & $\begin{array}{l}\text { It may not be suitable for thermolabile compounds, can produce dirty extracts which may need } \\
\text { further cleaning, expensive }\end{array}$ & {$[111]$} \\
\hline Microwave-assisted extraction & $\begin{array}{l}\text { Costly, thermo-labile polysaccharides can be degraded, may require filtration after the extrac- } \\
\text { tion process, high pressure and temperature used in closed vessel system can pose a safety } \\
\text { risk, the sample throughput is lower in open vessel system as it cannot process many samples } \\
\text { simultaneously }\end{array}$ & {$[112,113]$} \\
\hline Enzyme assisted extraction & $\begin{array}{l}\text { Expensive, sometimes enzymes are not able to completely rupture the cell wall, complexity in } \\
\text { usage, the efficiency of an enzyme is dependent on various environmental factors that's why } \\
\text { not feasible for industrial application }\end{array}$ & {$[114,115]$} \\
\hline Photobleaching & $\begin{array}{l}\text { Costly, can give different results depending on the changing weather conditions, can cause } \\
\text { chemical alterations in the molecule }\end{array}$ & {$[116]$} \\
\hline Reactive extrusion & The size of reactors used is big, costly, less explored & {$[107,111]$} \\
\hline High hydrostatic pressure & Can affect the structure and activity of polysaccharide & {$[106,117]$} \\
\hline
\end{tabular}




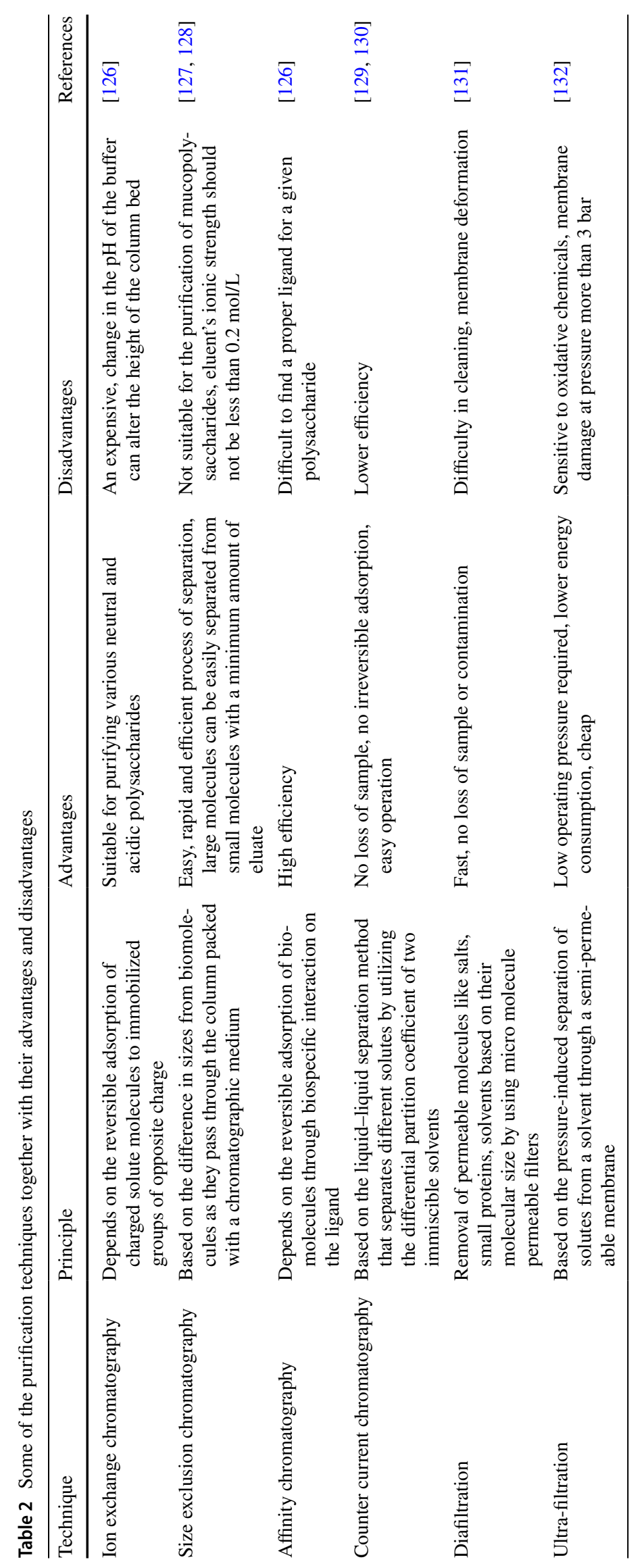


Table 3 Polysaccharides purified from seaweeds with their experimental conditions

\begin{tabular}{|c|c|c|c|}
\hline Polysaccharide & Seaweed & Experimental conditions & References \\
\hline Crude Polysaccharide & Grateloupia livida & $\begin{array}{l}\text { DEAE Sepharose CL-6B }(2.6 \times 30 \mathrm{~cm}) \\
\text { eluted with } \mathrm{H}_{2} \mathrm{O}\end{array}$ & {$[133]$} \\
\hline (CLP) & Caulerpa lentillifera & $\begin{array}{l}\text { DEAE cellulose } 52 \text { anion exchange col- } \\
\text { umns }(5.0 \times 50 \mathrm{~cm}) \text { eluted with } \mathrm{NaCl}\end{array}$ & [134] \\
\hline Crude Ecklonia kurome polysaccharides & $\begin{array}{l}\text { Ecklonia cava subsp. Kurome (formerly } \\
\text { known as Ecklonia kurome) }\end{array}$ & $\begin{array}{l}\text { DEAE- } 52 \text { cellulose column }(2.6 \times 30 \mathrm{~cm}) \\
\text { eluted by distilled water }\end{array}$ & {$[135]$} \\
\hline Sulphated polysaccharides & $\begin{array}{l}\text { Polycladia indica (formerly known as } \\
\text { Cystoseira indica) }\end{array}$ & $\begin{array}{l}\text { DEAE Sepharose Fast Flow column, } \\
\text { eluted with distilled water }\end{array}$ & [136] \\
\hline Exopolysaccharide & $\begin{array}{l}\text { Porphyridium purpureum (formerly } \\
\text { known as Porphyridium cruentum) }\end{array}$ & Diafiltration $(0.14 \mu \mathrm{m}$ ceramic membrane $)$ & [137] \\
\hline $\begin{array}{l}\text { polysaccharides from Gracilaria rubra } \\
\text { (GRPS) }\end{array}$ & $\begin{array}{l}\text { Gracilaria dura (formerly known as } \\
\text { Gracilaria rubra) }\end{array}$ & $\begin{array}{l}\text { DEAE-52 cellulose column }(2.630 \mathrm{~cm}) \\
\text { eluted with distilled water }\end{array}$ & [138] \\
\hline sulphated polysaccharides & Sargassum tenerrimum & $\begin{array}{l}\text { DEAE-Sepharose anion-exchange chro- } \\
\text { matography }((2 \mathrm{~cm} \times 15 \mathrm{~cm}) \text { eluted with } \\
\text { Tris HCl buffer }\end{array}$ & {$[16]$} \\
\hline Polysaccharide & Chlorella sp. & $\begin{array}{l}\text { DEAE Sepharose }(1.2 \mathrm{~cm} \times 20 \mathrm{~cm}) \text { eluted } \\
\text { with PBS }\end{array}$ & [139] \\
\hline Laminarin & $\begin{array}{l}\text { Gongolaria barbata (formerly known as } \\
\text { Cystoseira barbata) }\end{array}$ & $\begin{array}{l}\text { Ultrafiltration using } 50 \mathrm{kDa} \text { cut-off mem- } \\
\text { branes }\end{array}$ & [140] \\
\hline
\end{tabular}

Even though an array of purification techniques has been established but still, there are no standard protocols for the utilization of these techniques in the specific area. For example, in the food industry, the crude seaweed polysaccharide is primarily obtained using ethanol precipitation and membrane separation. Simultaneously, affinity chromatography and size exclusion chromatography are applied in pharmaceutical industries for procuring high-grade fractions of polysaccharides [8].

The bioactivities of algal polysaccharides are closely linked to their structures. Therefore, elucidating the structural characteristics of algal polysaccharides can play an important role in exploring their biological activity [140]. The structural characterization of algal polysaccharide involves the analysis of their monosaccharide composition, molecular weight determination, type of glycosidic bonds and their backbone structure. The analytical techniques majorly applied by the researchers for the determination of polysaccharide structure comprises high-performance liquid chromatography (HPLC) [141], Fourier transforms infrared spectroscopy (FT-IR) [142], nuclear magnetic resonance (NMR) [143], a hyphenated gas chromatography-mass spectroscopy (GC-MS) [144], x-ray diffraction method [145], ultra-violet spectroscopy [146]. However, the existence of sulphate groups in algal polysaccharides pose an additional challenge in determining their structure as the position and degree of sulphation, has to be further identified. Generally, HPLC, NMR, turbidometric barium chloride method, IR spectroscopy are performed to identify the degree and position of sulphate groups in algal polysaccharides [147-149]. All the above-mentioned techniques can provide a clear understanding of the obtained polysaccharide's morphology, crystallization, functional groups and physical strength for successful future biological applications.

\section{Bioactivities and Possible Health Application of Algal Polysaccharide}

Algal polysaccharides have been comprehensively explored for their diverse bioactivities such as antiviral, immunomodulatory, anticancer, antioxidant, anti-ageing, anticoagulant and anti-adhesive effects due to their different structural features.

\section{Antiviral Activity}

In recent times, a large number of infectious diseases have aroused due to the emerging or re-emerging of viruses. Viral outbreaks have always been a topic of concern as they pose severe challenges to human health. Thus, the developments of efficient antiviral drugs with novel formulations are urgently needed. Researchers globally have reported that polysaccharides isolated from algae have active antiviral properties with low toxicity and resistance [150]. These algae contain a significant amount of complex structural polysaccharides that have displayed the capability to block the various phases of the viral infection process (Fig. 6) in the members of togavirus, flavivirus, rhabdovirus, arenavirus and herpesvirus [151]. Low molecular weight polysaccharide from Ulva australis (formerly known as Ulva pertusa) and Grateloupia filicina displayed a notable antiviral activity against Avian Leucosis Virus Subgroup J [152, 153]. It 


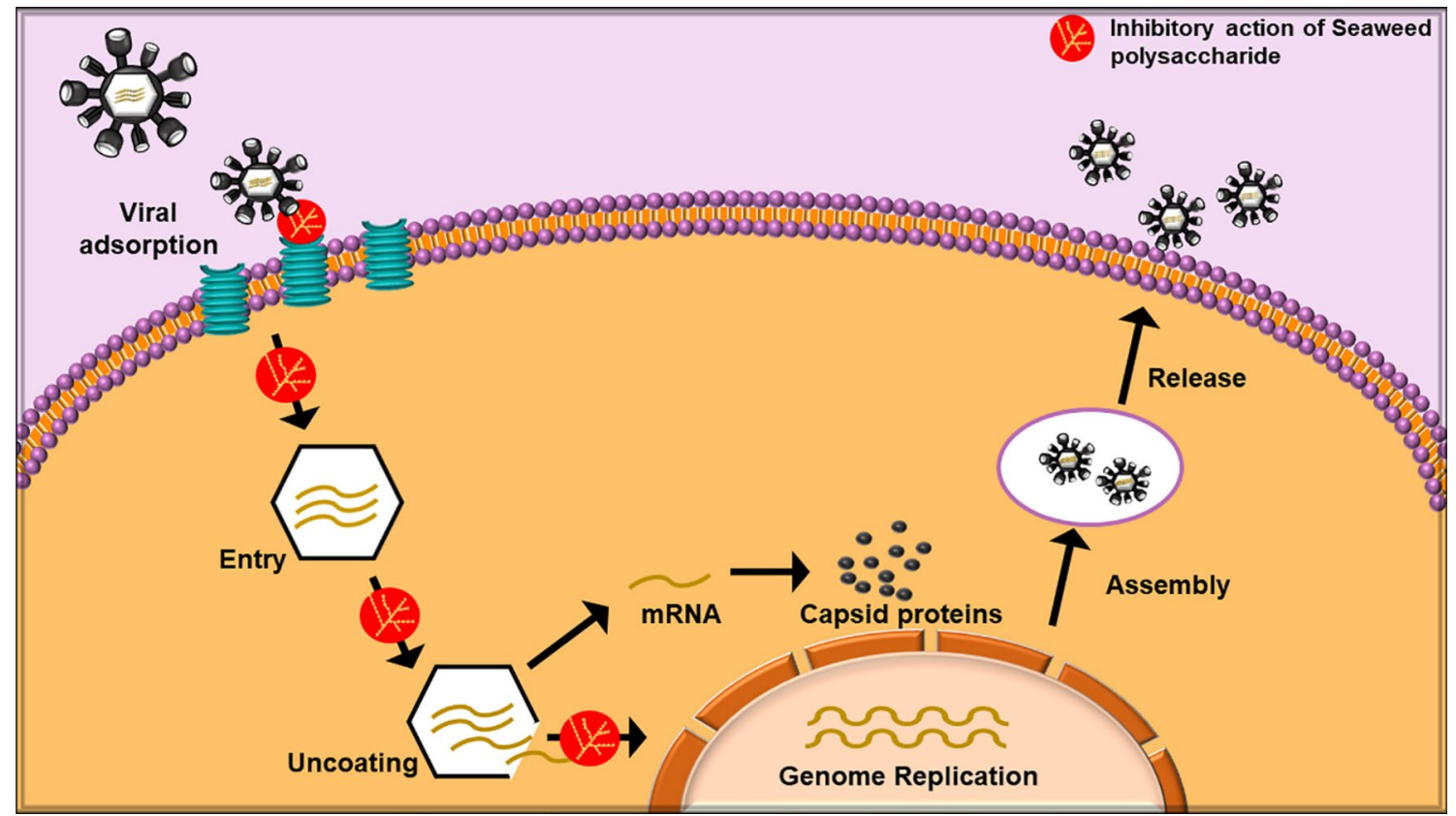

Fig. 6 Viral infection cycle and antiviral activity of seaweed polysaccharides

was found that such low molecular weight polysaccharides purified from their respective algae inhibited the adsorption of the virus onto the host cell. Alboofetileh et al. [57] demonstrated the strong antiviral activity of fucoidan isolated from brown alga Nizamuddinia zanardinii against Herpes Simplex Virus-2 infection. Cao et al. [154] reported the antiviral activity of polysaccharide extracted from Saccharina japonica (formerly known as Laminaria japonica) against the respiratory syncytial virus. The results showed that EC50 of the polysaccharide extract to the virus was $5.27 \mathrm{mg} / \mathrm{ml}$. Moreover, the polysaccharide was found to improve the expression of interferon regulatory factor-3 (IRF-3) which led to enhanced production of interferon- $\alpha$ (IFN- $\alpha$ ) eliciting antiviral activity. The antiviral activity of water-soluble polysaccharide, sulphated glucuronorhamnan from green seaweed Monostroma nitidum against the enterovirus 71 was studied by Wang et al. [155]. The results reported that the sulphated polysaccharide inhibited the enterovirus 71 infection by adsorbing to the virus particles and blocking some of the initial steps of the virus life cycle by down-regulating host phosphoinositide 3-kinase/protein kinase B signalling pathway. Moreover, various types of polysaccharides namely, alginate, fucan, ulvan, glycan, dextran, fucoidan, laminarin have been reported to possess an extensive range of antiviral behaviour in vitro against herpes simplex virus, dengue virus, influenza virus and immunodeficiency virus [156-160]. Thus, it can be summarized that seaweed polysaccharides can be presented as effective, less toxic antiviral agents having great potential in medicine. However, the accurate antiviral mechanism of algal polysaccharides and the impact of algal polysaccharides structure on the antiviral activity is still vague and needs a deeper study in the coming future.

\section{As an Immunostimulant}

Stimulation of the immune system is considered as one of the prime defence strategies of the body for combating foreign invaders. In recent times, algal polysaccharides have aroused a lot of interest in the regulation of the immune system due to their low toxicity and structural variation. Algal polysaccharides are known to protect cells by directly or indirectly interacting with the immune system and activating several signalling pathways (Fig. 7). A lot of studies have established that algal polysaccharides have efficacious immunostimulant activities both in vitro and in vivo. Sulphated polysaccharide named UPP-2 isolated from Undaria pinnatifida has been reported to promote the pinocytic activity of RAW264.7 macrophages cells and enhanced the secretions of nitric oxide, tumour necrosis factor- $\alpha$ (TNF- $\alpha$ ) and interleukin-6 (IL-6) by 8.0, 73.1 and 188.7 times compared to those of the negative control, respectively [161]. Similarly, crude polysaccharides from Chloroidium ellipsoideum (formerly known as Chlorella ellipsoidea) stimulated murine macrophage, RAW264.7 cells, to significantly produce considerable amounts of various cytokines and nitric oxide by the activation of nuclear factor-kappa B (NF-B) and mitogen-activated protein kinase (MAPK) pathways [162]. In a study by Sun et al. [137], the in vitro immunostimulatory activity of a 


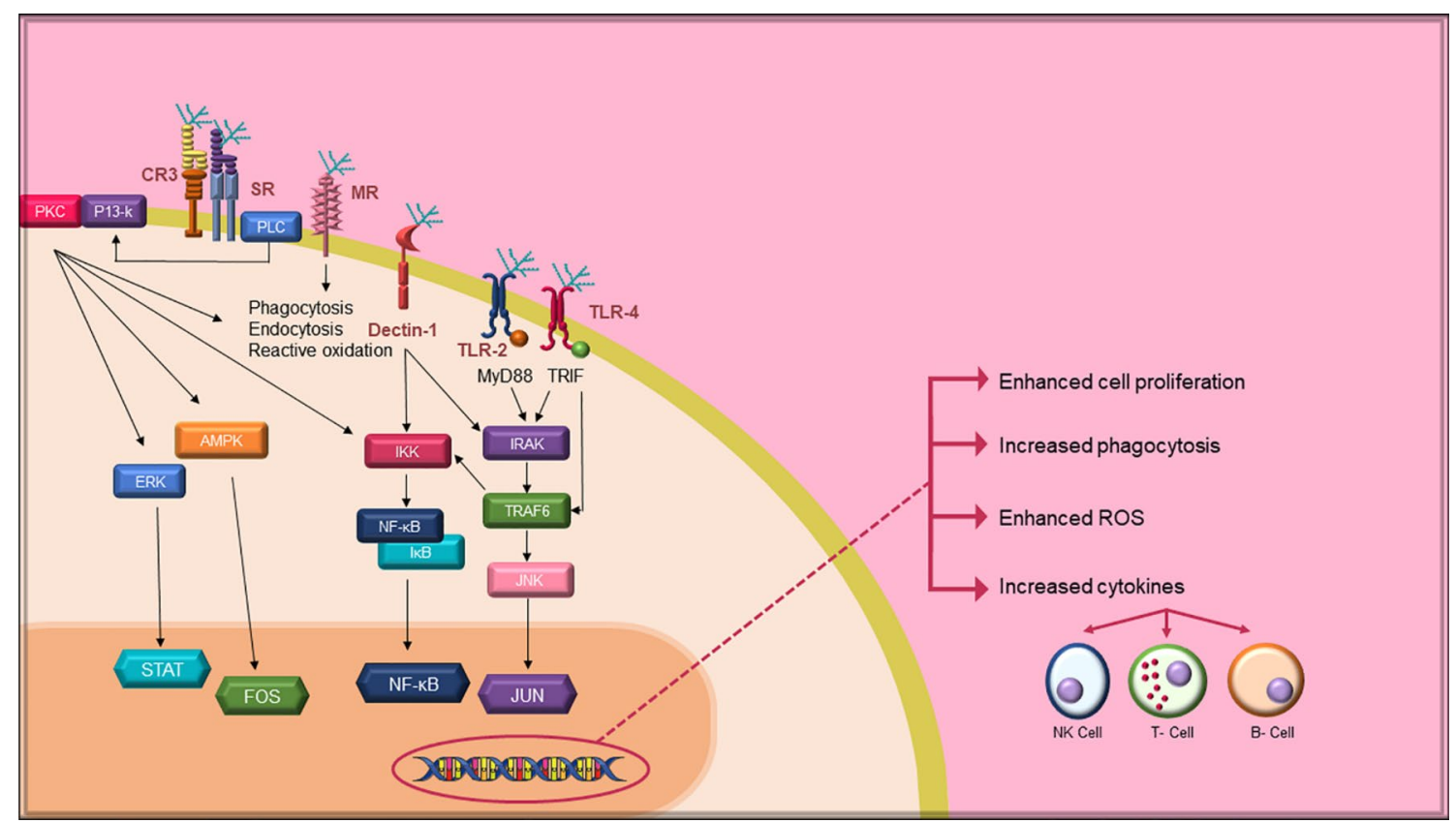

Fig. 7 Signalling pathways involved in immune system activation by seaweed polysaccharides. PKC: protein kinase C; PI3-K: phosphatidylinositol 3 kinase; CR3: complement receptor 3; SR: scavengers receptors; PLC: phospholipase C; MR: mannose receptors; Dectin-1: dendritic cell-associated C-type lectin-1; TLR-2: Toll-like receptor-2; TLR-4: Toll-like receptor-4; MyD88: myeloid differentiation factor 88; TRIF: Toll/IL-1 domain-containing adaptor inducing interferon

purified polysaccharide isolated from Caulerpa lentillifera was evaluated. The findings stated that the polysaccharide fractions stimulated macrophages activity by enhancing acid phosphatase activity, phagocytosis and nitric oxide production. Likewise, a water-soluble polysaccharide named CRVP-1, obtained from Caulerpa chemnitzia (formerly known as Caulerpa racemosa var peltate) proliferated the activity of macrophages, secretion of cytokines and production of nitric oxide [163]. Di et al. [138] observed that crude polysaccharide procured from $\mathrm{Graci}$ laria dura (formerly known as Gracilaria rubra) exhibited immunostimulatory activity on RAW264.7 macrophages cell. Two polysaccharides designated as SCP1 and SCP2, isolated from Sargassum carpophyllum demonstrated immunostimulatory activity by promoting the secretion of cytokines, interleukin-2 (IL-2) and tumour necrosis factor- $\alpha($ TNF- $\alpha)$ [164]. Recent studies have shown that Ulva australis (formerly known as Ulva pertusa) polysaccharide promotes the proliferation and phagocytic activity of macrophage, release of nitric oxide, and secretion of TNF- $\alpha$ and IL-6 [165]. The immunostimulant activity of algal polysaccharides is largely determined by their structural characteristics that include molecular weight, functional groups, glycosidic bonds and monosaccharide composition. In the past, some studies have been done $\beta$; ERK: extracellular signal-regulated kinase; STAT: signal transducers and activators of transcription; IKK: inhibitor of nuclear factor kappa-B kinase; NF-кB: nuclear factor kappa-B; IкB: inhibitor of nuclear factor kappa-B; IRAK: interleukin-1 receptor-associated kinase; TRAF6: tumour necrosis factor receptor-associated factor-6; JNK: Jun N-terminal kinase

on the relationship between polysaccharide structure and immunostimulant activity. In a study, Mehdi Tabarsa et al. [166] isolated two fractions of sulphated polysaccharides from Ulva intestinalis, namely, F1 and F2 with a molecular weight of $87.1 \times 10^{3}$ and $194.1 \times 10^{3} \mathrm{~g} / \mathrm{mol}$, respectively. They reported that the immunostimulant activity of polysaccharide fractions was dependent on their molecular weight. According to their study, lower molecular weight fraction displayed enhanced immunostimulant activity. In another study reported by Qi and Kim [162], the polysaccharide fractions (F1 and F2) of Chloroidium ellipsoideum (formerly known as Chlorella ellipsoidea) stimulated the immunomodulatory activity. However, in this study, the polysaccharide fraction with high molecular weight and protein concentration showed stronger immunostimulant activity. Thus, the relationship between molecular weight and immunostimulant activity of algal polysaccharide is still not clear and needs improvement. Also, it is very difficult to depict the exact details concerning the impact of molecular weight on the algal immunostimulatory activity of polysaccharide by carrying out the same experiments on polysaccharides with different structures. A proper technique that maintains the intact structural features of different polysaccharides, can be effective to investigate the relationship between molecular weight and activity. 
Moreover, the relationship between other structural features and immunostimulatory activity is rarely stated and therefore requires detailed investigation.

\section{Anticancer Activities}

Cancer, one of the most fatal diseases, is the major cause of mortality across the globe, accounting for approximately 9.6 million deaths in recent years [167]. Generally, chemotherapy is used in the treatment of cancer but it has certain side effects such as anaemia, fatigue, alopecia, and fertility issues, to quote a few of them [168]. Therefore, it becomes important to search for a natural alternative source that can help in combating this life-threatening disease. Polysaccharides acquired from algae have been shown to possess anticancer activity both in vivo and in vitro conditions. Anticancer activities of algal polysaccharides (Fig. 8) are brought about by the following mechanisms: (1) cell cycle arrest (2) depolarization of mitochondrial membrane (3) production of nitric oxide (4) stimulation of immune system against cancer cells (4) apoptosis of tumour [169]. Vaikundamoorthy et al. [169] investigated the anticancer properties of polysaccharide fraction obtained from Sargassum wightii on human breast cancer cells (MCF7 and MDA-MB-231). The results demonstrated that polysaccharides caused apoptosis of breast cancer cells by enhancing ROS generation, breaking the mitochondrial membrane, causing nuclei damage and eventually causing an increase in the activity of caspase 3/9. Fucoidan isolated from Sargassum ilicifolium (formerly known as Sargassum duplicatum) was found to be effective against colony formation of colon cancer cells in vitro [170]. The anticancer impact of polysaccharides, laminarin and fucoidan obtained from brown alga Dictyota dichotoma was explored in vitro on colon cancer cells (HCT116, HT-29, and DLD-1). The results indicated a decrease in the amount and size of cancer cells colonies [171]. The sulphated fucoidan obtained from Padina boryana inhibited the colony formation of colorectal carcinoma cells DLD-1 and HCT-116 in vitro [172]. Gheda et al. [173] reported that polysaccharide extracted from red alga Jania rubens caused apoptosis in colon and breast cancer cell lines. Laminarins procured from brown seaweeds inhibited proliferation, colony formation, and migration of human colorectal adenocarcinoma, melanoma, and breast adenocarcinoma cells [174]. Chen et al. [175] stated that the sulphated polysaccharides from Tribonema sp. induced cell apoptosis on HepG2 cells. Further, Neoporphyra haitanensis (formerly known as Porphyra haitanensis) polysaccharides had a significant anticancer effect on human colon cancer cells by apoptosis and cell cycle arrest [176]. Based on these encouraging results, seaweed polysaccharides could be effectively utilized as alternative therapeutics for the treatment of various human cancers. Although a lot of research has been published on the in vitro anticancer activity of algal polysaccharide, negligible work has been performed on in vivo studies, which further requires detailed investigation. Moreover, only a few studies on the in vitro relationship between algal polysaccharide structure-antiviral activity has been reported, wherein,

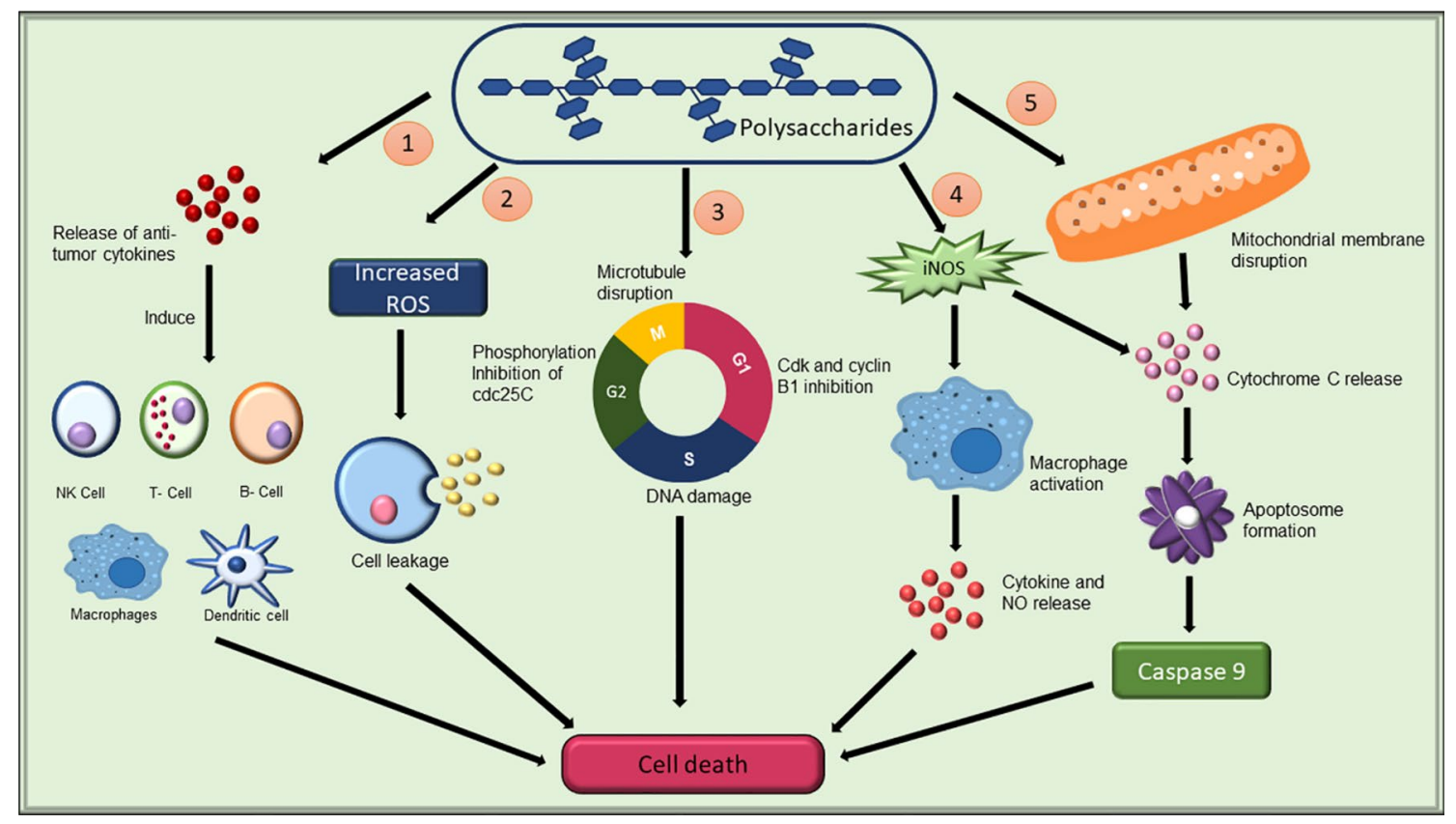

Fig. 8 Anticancer activity of seaweed polysaccharide. 1: immunomodulation; 2: cytotoxicity; 3: cell cycle arrest; 4:NO dependent pathway; 5: mitochondrial disruption 
structural features such as molecular weight and uronic acid content of the polysaccharide have been considered as the major factor in determining antiviral activity [177, 178]. Thus, thorough research on the in vivo and in vitro structure-activity relationship is required in the time to come.

\section{Antidiabetic Activities}

Diabetes mellitus is a chronic metabolic dysfunction that jeopardizes human health with a large number of deaths and illness, after cardiovascular diseases and cancer [151]. Diabetes mellitus has affected around 9.3\% of the global adult population by the year 2019 and it is expected to rise to almost $11 \%$ by 2045 [179]. Currently, the treatment of diabetes mellitus employs the use of synthetic chemical drugs that can induce certain side effects and toxicity, endangering the patient's health. As a result, there is an immediate need for an alternative, natural and non-toxic antidiabetic agent that can overcome the limitations of synthetic drugs. Recently, algal polysaccharides were established to have favourable impacts on the treatment of diabetes mellitus. Jia et al. [180] reported that polysaccharides extracted from algae Ascophyllum nodosum, Fucus vesiculosus and Undaria pinnatifida reduced the blood glucose level in diabetic rats. Polysaccharide isolated from Gracilaria opuntia possessed significant antidiabetic properties [181]. Koh et al. [182] stated that fucoidan extracted from Undaria pinnatifida demonstrated considerably stronger inhibiting effects towards $\alpha$-glucosidase than $\alpha$-amylase, thus having excellent properties as an antidiabetic agent. The antidiabetic effect of Sargassum confusum polysaccharide hydrolysates in Insulin Resistance HepG2 Cells was investigated in vitro by Yang et al. [183]. The results demonstrated that the polysaccharide hydrolysate not only exhibited strong inhibitory action against $\alpha$-glucosidase with an IC50 value of $9.9 \mathrm{mg} / \mathrm{ml}$ but also amplified the consumption of glucose and enhanced insulin resistance in insulin-resistance HepG2 cells. Furthermore, polysaccharides extracted from Undaria pinnatifida reduced blood glucose level, enhanced glucose tolerance and insulin resistance in HFD/STZ-induced hyperglycaemic mice [184]. Thus, it can be inferred that seaweed polysaccharides can serve as a non-toxic, cheap, potential alternative as therapeutic agents in the treatment of diabetes. However, neither structure-activity relationship is established properly nor sufficient clinical trial studies are performed to assess the algal polysaccharide efficiency as antidiabetic agents. Thus, a comprehensive research should be done to utilize the algal polysaccharides effectively as an agent to treat diabetes.

\section{Antioxidant Activity}

Increased free radicals in living organisms can damage the immune system, cause ageing, arthritis, cancer and several other cardiovascular and neurodegenerative diseases [185]. Recent research has reported that algal polysaccharides play a significant role in the dissolution of free radicals, subsequently, decreasing the oxidative damage in living organisms. The sulphated polysaccharide extracted from Navicula sp. presented $49 \%$ and $68 \mathrm{mmol}$ Trolox/g scavenging activity against 2,2-diphenyl-1-picrylhydrazyl (DPPH) and 2,2-azino-bis(3-etilbenzotiazolin)-6-sulphonic acid $\left(\mathrm{ABTS}^{+}\right)$, respectively [186]. Jaballi et al. [187] established the antioxidant activity of polysaccharide obtained from red marine macroalga Mazzaella canaliculata (formerly known as Chondrus canaliculatus). Khan et al. [188] described that Neoporphyra haitanensis (formerly known as Porphyra haitanensis) polysaccharides exhibited $53.16 \%$ of radical scavenging activity against $\mathrm{ABTS}^{+}$.

The antioxidant activity of the fucoidan procured from Spatoglossum asperum was evaluated by Palanisamy et al. [189]. The findings mentioned the DPPH radical scavenging activity and reducing the power of fucoidan. Similarly, fucoidan extracted from brown seaweed Cystoseira compressa also exhibited strong antioxidant activities by ferrous ion chelation, ferric ion reduction and DPPH radical scavenging [190]. Le et al. [87] evaluated the antioxidant activity of polysaccharide ulvan extracted from Ulva australis (formerly known as Ulva pertusa). They stated that ulvan exhibited reducing power in vitro and had a very strong antioxidant activity against $\mathrm{DPPH}$ and $\mathrm{ABTS}^{+}$. Moreover, ulvan also protected RAW 264.7 cells against $\mathrm{H}_{2} \mathrm{O}_{2}$-induced oxidative stress by enhancing the activity of superoxide dismutase (SOD) and catalase (CAT). Likewise, a crude polysaccharide obtained from Chnoospora minima displayed strong DPPH and alkyl radical scavenging activities and enhanced reactive oxygen species scavenging actions for both 2,2-azobis(2amidinopropane) dihydrochloride (AAPH) and $\mathrm{H}_{2} \mathrm{O}_{2}$ induced ROS production in "Chang" liver cell line [191]. Although, polysaccharides from different algal species displayed strong antioxidant activities, the actual mechanism of action of polysaccharides demands a detailed investigation. Also, it is reported that the structural features of algal polysaccharides such as molecular weight, monosaccharide make-up, degree and position of sulphation [164, 191, 192], greatly influence the antioxidant activity, however, how these features affect the activity, is yet unclear.

\section{Other Activities}

Other biological activities such as anti-glycation [193], anti-inflammatory [194-197], anti-microbial [198, 199], anti-coagulant [200-204], anti-ageing [205-209] and 
anti-obesity [208, 209] have also been recognized in seaweed polysaccharides.

\section{Relevant Patents}

A sift through one of the international databases "google patents" resulted in about 129,341 hits on algal extraction and its bioactivities. Since it is beyond the capability of this review to mention all the patents, we have limited this section to a couple of inventions (Table 4) related to the extraction, purification and biological activities of algal polysaccharides since 2017. Upon extensive searching, it was observed that a total number of 16,262 patents were filed since 2017, with China contributing to the maximum number of patents (7471). Thus, a large number of patent filing in this area of research states that new methods for extracting algal polysaccharides and their various therapeutic activities are being established and there is continuous demand for these natural polysaccharides.

\section{Challenges and Research Gaps}

A plenitude of data is available on the naturally occurring algal polysaccharides with medicinal perspective as anticancer, antiviral, antidiabetic, antifungal agents etc. However, for long-lasting socio-economic and environmental integrity, certain challenges need to be addressed. Although the advanced extraction techniques display high extraction efficiencies at low cost, these are still restricted to laboratory research and cannot be easily scaled up to large scale quantification. Also, majority of the studies on algal polysaccharide are based upon crude polysaccharide, which mainly contains heterogeneous polysaccharide, making it a challenge to depict a definite conclusion. Thus, measures should be taken to properly investigate the methods for the isolation of homogenous polysaccharides. Furthermore, fewer data on a detailed study of algal polysaccharide quality control makes it difficult to analyse the quality of the isolated polysaccharide. Hence, quality assessment of the isolated polysaccharide should be made mandatory, for successful utilization in various industries. Another major concern is the presence of proteins in the extracted polysaccharide. Thus, a cheap, environment-friendly technique should be developed to eliminate proteins from the samples. Additionally, extraction yields are at times quite low and need amelioration for industrial usage. Extracted polysaccharides exhibit immense structural diversity accounting for parameters such as algal species, growth factors, harvesting season, extraction and purification techniques, which is a significant challenge for commercial application. Moreover, elucidating the detailed structure of algal polysaccharide is essential to explore their structure-activity relationships and the underlying mechanism. However, the characterization analysis is mostly based on the monosaccharide composition and molecular weight. Hence, comprehensive research on their molecular structure should be done by applying advanced technologies. Furthermore, various therapeutic activities of algal polysaccharides are studied significantly, but their underlying mechanism must be examined in detail. With regards to the bioactivities of algal polysaccharides, most of the research is concentrated on in vitro studies. Currently, more intricate and pragmatic in vivo studies are lacking, affecting the extensive analysis and investigation of bioactivities of algal polysaccharides. Another issue is the lack of clinical testing of the extracted polysaccharides, which must be addressed, as clinical trials are required to authenticate the efficiency of the polysaccharides so that they can be successfully utilized in the health sector.

Due to the above-mentioned concerns, a broad scientific investigation is desperately needed in this particular field. Besides, several other questions remain unanswered that represent a huge research gap. Significant constraints and research gaps include but not restricted to: (1) negative effect on the marine ecosystem by excessive usage and exploitation of algae for various biological activities (2) short life span of the harvested algal biomass (3) fluctuations in various factors required for algal growth (4) different protocols to stabilize the bioactivities of algal polysaccharide extracted from differing algal species (5) environmental hazard associated with the application of algal polysaccharides in various bioactivities (6) impact of epiphytes and other marine organisms on the metabolic activity of the seaweeds which can later affect their extraction yield (7) in-depth in vivo studies of algal polysaccharides (8) algal polysaccharide application on humans.

\section{Future Perspective and Conclusion}

Due to the aforementioned concerns, the future scope in the extraction process of algal polysaccharides and their application in various bioactivities is huge. Since, the monosaccharide composition, molecular mass and structural properties of the extracted polysaccharide vary with the extraction methods, screening can be performed for selecting the appropriate extraction technique according to the particular application. Organic solvents in the extraction process could be replaced with cheap and environment-friendly water or agro-based solvents to improve the extraction yield. Additionally, the pilot-scale study of algal polysaccharide extraction must be conducted to produce data for industrial-scale production. Given that, the industries are under a lot of pressure, to utilize green extraction methods for obtaining polysaccharides, techno-economic analysis of innovative extraction methods should be performed to analyse the environmental and economic assessment on polysaccharide regeneration from algae. Kinetic studies should 


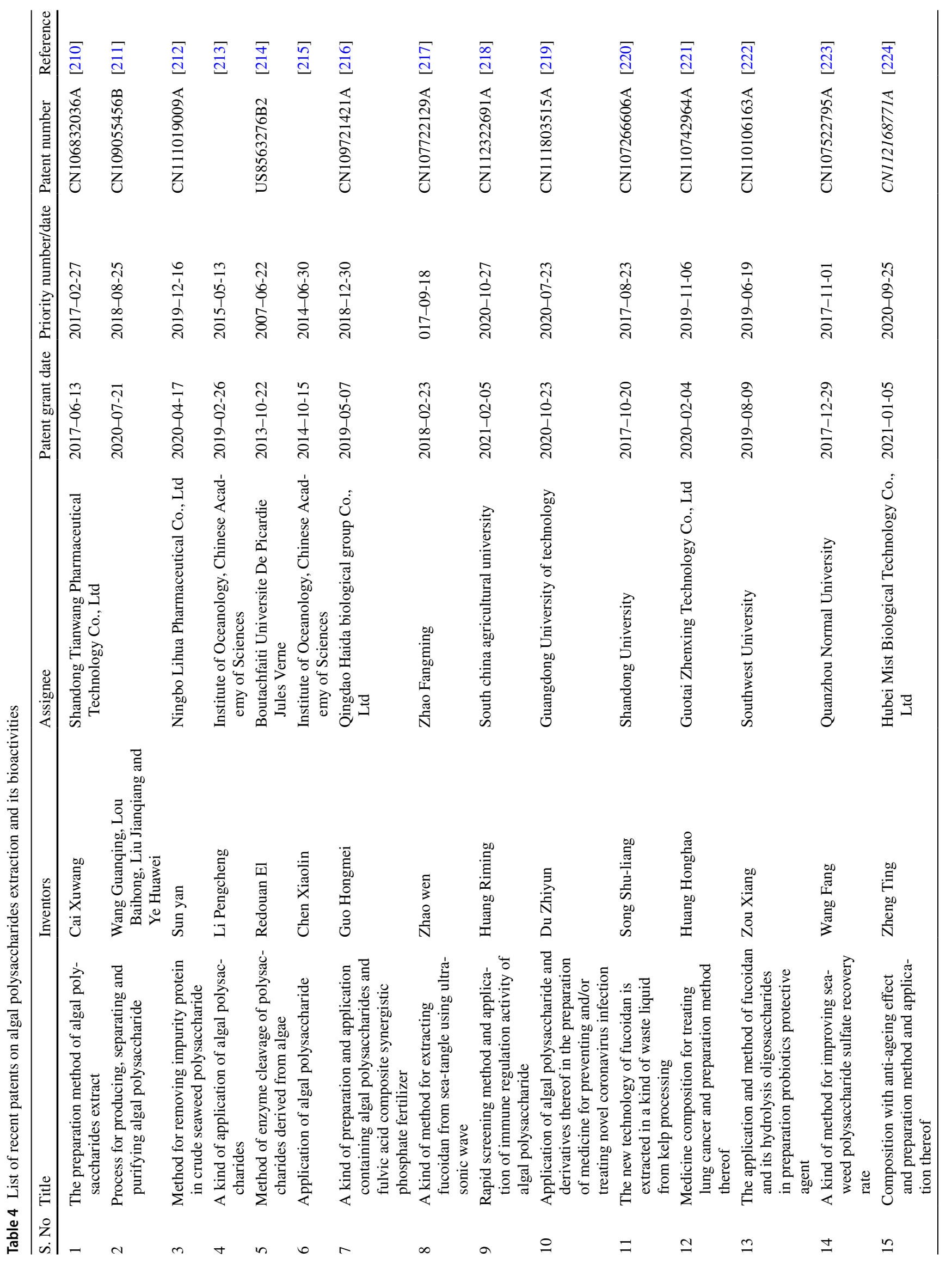


be performed to comprehend the relationship between different parameters and the underlying mechanism to predict the extraction yield. Also, statistical studies must be established in polysaccharides to examine their mechanism. Another interesting future application that can be looked into is the production of multiple value-added compounds instead of wastes during the extraction process. Moreover, selective modifications in the polysaccharides could be made during the extraction process to understand the structure-function relationship for performing in vivo studies for various biological activities. Although algal polysaccharides are recognised as eco-friendly and effective with few adverse effects, as compared to chemical drugs but still very few clinical trials are reported to date. More and more clinical analysis should be performed to validate the potency of algal polysaccharides in the prevention of diseases.

In conclusion, algal polysaccharides have aroused a lot of fascination amongst the research community globally, owing to their considerable health benefits. However, comprehensive study on their extraction techniques, structure, underlying mechanism and the structure-activity relationship remains ambiguous to a larger extent, making in-depth analysis of these polysaccharides a mandate. Although there are both opportunities and difficulties in this particular area of research, it is still rational to declare that algal polysaccharides, apparently have a great possibility in the health sector as natural drugs.

Acknowledgements We sincerely thank Amity Institute of Biotechnology, Amity University, Noida, for providing the infrastructure facilities required for this study.

Funding This research was supported by the Department of Science and Technology, India under the scheme for "Young Scientists and Technologists" (Grant No. SP/YO/283/2018).

\section{Declarations}

Conflict of interest The authors declare that they have no conflict of interest.

\section{References}

1. Jalilian N, Najafpour GD, Khajouei M (2020) Macro and micro algae in pollution control and biofuel production-a review. ChemBioEng Rev 7:18-33

2. Global Algae Industry. https://www.reportlinker.com/p0580 0022/Global-Algae-Industry.html. Accessed 8 Apr 2021

3. Gomez-Zavaglia A, Prieto Lage MA, Jimenez-Lopez C et al (2019) The potential of seaweeds as a source of functional ingredients of prebiotic and antioxidant value. Antioxidants 8:406

4. Radulovich R, Neori A, Valderrama D et al (2015) Farming of seaweeds. In: Tiwari BK (ed) Seaweed sustainability: food and non-food applications. Elsevier, Amsterdam, pp 27-59
5. Alba K, Kontogiorgos V (2018) Seaweed polysaccharides (agar, alginate carrageenan). In: Varelis P et al (eds) Encyclopedia of food chemistry. Elsevier, Amsterdam, pp 240-250

6. Usman A, Khalid S, Usman A et al (2017) Algal polysaccharides, novel application, and outlook. In: Zia K et al (eds) Algae based polymers, blends, and composites: chemistry, biotechnology and materials science. Elsevier, Amsterdam, pp 115-153

7. Venugopal V (2019) Sulfated and non-sulfated polysaccharides from seaweeds and their uses: an overview. ECronicon Nutr 2:126-141

8. Xu S-Y, Huang X, Cheong K-L (2017) Recent advances in marine algae polysaccharides: isolation, structure, and activities. Mar Drugs 15:388. https://doi.org/10.3390/md15120388

9. Prajapati VD, Maheriya PM, Jani GK, Solanki HK (2014) Carrageenan: a natural seaweed polysaccharide and its applications. Carbohydr Polym 105:97-112. https://doi.org/10.1016/j.carbpol. 2014.01.067

10. Kraan S (2012) Algal polysaccharides, novel applications and outlook. In: Chang CF (ed) Carbohydrates-comprehensive studies on glycobiology and glycotechnology. In Tech, Singapore

11. Patel S (2012) Therapeutic importance of sulfated polysaccharides from seaweeds: updating the recent findings. 3 Biotech 2:171-185. https://doi.org/10.1007/s13205-012-0061-9

12. Tziveleka LA, Ioannou E, Roussis V (2019) Ulvan, a bioactive marine sulphated polysaccharide as a key constituent of hybrid biomaterials: a review. Carbohydr Polym 218:355-370

13. Oliveira C, Ferreira AS, Novoa-Carballal R et al (2017) The key role of sulfation and branching on fucoidan antitumor activity. Macromol Biosci. https://doi.org/10.1002/mabi.201600340

14. Shanmugam M, Mody KH (2000) Heparinoid-active sulphated polysaccharides from marine algae as potential blood anticoagulant agents. Curr Sci 79:1672-1683

15. Garcia-Vaquero M, Rajauria G, O'Doherty JV, Sweeney T (2017) Polysaccharides from macroalgae: recent advances, innovative technologies and challenges in extraction and purification. Food Res Int 99:1011-1020. https://doi.org/10.1016/j.foodres.2016. 11.016

16. Mohan MSG, Achary A, Mani V et al (2019) Purification and characterization of fucose-containing sulphated polysaccharides from Sargassum tenerrimum and their biological activity. J Appl Phycol 31:3101-3113. https://doi.org/10.1007/ s10811-019-01797-7

17. Hjelland, Finn. Hanning, Arne. and Yang H (2012) Process for Isolating Fucoidan and Laminarin From Live, Harvested Seaweed. Google Patents 7

18. Senni K, Pereira J, Gueniche F et al (2011) Marine polysaccharides: a source of bioactive molecules for cell therapy and tissue engineering. Mar Drugs 9:1664-1681

19. Saqib A, Tabbssum MR, Rashid U et al (2013) Marine macroalgae Ulva: a potential feed-stock for bioethanol and biogas production. Asian J Agri Biol 1:155-163

20. Leandro A, Pereira L, Gonçalves AMM (2020) Diverse applications of marine macroalgae. Mar Drugs 18:17

21. January GG, Naidoo RK, Kirby-McCullough B, Bauer R (2019) Assessing methodologies for fucoidan extraction from South African brown algae. Algal Res. https://doi.org/10.1016/j.algal. 2019.101517

22. Sellimi S, Maalej H, Rekik DM et al (2018) Antioxidant, antibacterial and in vivo wound healing properties of laminaran purified from Cystoseira barbata seaweed. Int J Biol Macromol 119:633-644. https://doi.org/10.1016/j.ijbiomac.2018.07.171

23. Mohamed SF, Slamy TM, Shaeiri SY (2015) Characterization of sulphated polysaccharide with antiviral activity from marine brown alga Cystoseira myrica collected from Jazan coasts, KSA. Int J PharmTech Res 8:198-203 
24. Deghrigue Abid M, Lajili S, Hadj Ammar H et al (2019) Chemical and biological properties of sodium alginates isolated from tow brown algae dictyopteris membranaceae and padina pavonica. Trends J Sci Res 4:62-67. https://doi.org/10.31586/pharm acology.0402.03

25. Bensah EC, Mensah M (2013) Chemical pretreatment methods for the production of cellulosic ethanol: technologies and innovations. Int J Chem Eng 2013:719607

26. Huang CY, Wu SJ, Yang WN et al (2016) Antioxidant activities of crude extracts of fucoidan extracted from Sargassum glaucescens by a compressional-puffing-hydrothermal extraction process. Food Chem 197:1121-1129. https://doi.org/10.1016/j.foodc hem.2015.11.100

27. Song YR, Han AR, Park SG et al (2020) Effect of enzymeassisted extraction on the physicochemical properties and bioactive potential of lotus leaf polysaccharides. Int J Biol Macromol 153:169-179. https://doi.org/10.1016/j.ijbiomac.2020.02.252

28. Kasipandi M, Vrindarani AS, Sreeja PS et al (2019) Effect of in vitro simulated digestion on sugar content and biological activities of Zehneria maysorensis (Wight \& Arn.) Arn. leaf polysaccharides. J Food Meas Charact 13:1765-1772. https:// doi.org/10.1007/s11694-019-00094-8

29. Shao L, Sun Y, Liang J et al (2020) Decolorization affects the structural characteristics and antioxidant activity of polysaccharides from Thesium chinense Turcz: comparison of activated carbon and hydrogen peroxide decolorization. Int J Biol Macromol 155:1084-1091. https://doi.org/10.1016/j.ijbiomac.2019.11.074

30. Masci A, Carradori S, Casadei MA et al (2018) Lycium barbarum polysaccharides: extraction, purification, structural characterisation and evidence about hypoglycaemic and hypolipidaemic effects. A review. Food Chem 254:377-389

31. Wang F, Ma Y, Liu Y et al (2017) A simple strategy for the separation and purification of water-soluble polysaccharides from the fresh Spirulina platensis. Sep Sci Technol 52:456-466. https:// doi.org/10.1080/01496395.2016.1244549

32. He X, Fang J, Ruan Y et al (2018) Structures, bioactivities and future prospective of polysaccharides from Morus alba (white mulberry): a review. Food Chem 245:899-910

33. Abraham RE, Su P, Puri M et al (2019) Optimisation of biorefinery production of alginate, fucoidan and laminarin from brown seaweed Durvillaea potatorum. Algal Res. https://doi.org/10. 1016/j.algal.2018.101389

34. Chi Y, Li H, Wang P et al (2020) Structural characterization of ulvan extracted from Ulva clathrata assisted by an ulvan lyase. Carbohydr Polym. https://doi.org/10.1016/j.carbpol.2019.115497

35. Hifney AF, Fawzy MA, Abdel-Gawad KM, Gomaa M (2016) Industrial optimization of fucoidan extraction from Sargassum sp. and its potential antioxidant and emulsifying activities. Food Hydrocoll 54:77-88. https://doi.org/10.1016/j.foodhyd.2015.09. 022

36. Meinita MDN, Marhaeni B, Jeong GT, Hong YK (2019) Sequential acid and enzymatic hydrolysis of carrageenan solid waste for bioethanol production: a biorefinery approach. J Appl Phycol 31:2507-2515. https://doi.org/10.1007/s10811-019-1755-8

37. Ray B, Schütz M, Mukherjee S et al (2020) Exploiting the amazing diversity of natural source-derived polysaccharides: modern procedures of isolation, engineering, and optimization of antiviral activities. Polymers (Basel) 13:136. https://doi.org/10.3390/ polym 13010136

38. Ivanović M, Razboršek MI, Kolar M (2020) Innovative extraction techniques using deep eutectic solvents and analytical methods for the isolation and characterization of natural bioactive compounds from plant material. Plants 9:1-29

39. Zhang Q, Vigier K, Royer S et al (2012) Deep eutectic solvents: syntheses, properties and applications. Chem Soc Rev 41:7108-7146
40. Meksi N, Moussa A (2017) A review of progress in the ecological application of ionic liquids in textile processes. J Clean Prod 161:105-126

41. Rai A, Mohanty B, Bhargava R (2016) Fitting of broken and intact cell model to supercritical fluid extraction (SFE) of sunflower oil. Innov Food Sci Emerg Technol 38:32-40. https:// doi.org/10.1016/j.ifset.2016.08.019

42. Salea R, Veriansyah B, Tjandrawinata RR (2017) Optimization and scale-up process for supercritical fluids extraction of ginger oil from Zingiber officinale var. Amarum. J Supercrit Fluids 120:285-294. https://doi.org/10.1016/j.supflu.2016.05. 035

43. García-Pérez JS, Cuéllar-Bermúdez SP, Arévalo-Gallegos A et al (2020) Influence of supercritical CO2 extraction on fatty acids profile, volatile compounds and bioactivities from Rosmarinus officinalis. Waste and Biomass Valorization 11:1527-1537. https://doi.org/10.1007/s12649-018-0408-5

44. Carissimi G, Montalbán MG, Díaz Baños FG, Víllora G (2018) High pressure phase equilibria for binary mixtures of $\mathrm{CO} 2+$ 2-pentanol, vinyl butyrate, 2-pentyl butyrate or butyric acid systems. J Supercrit Fluids 135:69-77. https://doi.org/10.1016/j. supflu.2018.01.003

45. Paula JT, Sousa IMO, Foglio MA, Cabral FA (2018) Selective fractionation of extracts of Arrabidaea chica Verlot using supercritical carbon dioxide as antisolvent. J Supercrit Fluids 133:9-16. https://doi.org/10.1016/j.supflu.2017.09.021

46. Michalak I, Dmytryk A, Wieczorek PP et al (2015) Supercritical algal extracts: a source of biologically active compounds from nature. J Chem 2015:1

47. Abhari K, Mousavi Khaneghah A (2020) Alternative extraction techniques to obtain, isolate and purify proteins and bioactive from aquaculture and by-products. In: Advances in Food and Nutrition Research. Elsevier, Amsterdam, pp 35-52

48. Quitain AT, Kai T, Sasaki M, Goto M (2013) Microwave-hydrothermal extraction and degradation of fucoidan from supercritical carbon dioxide deoiled Undaria pinnatifida. ACS Publ 52:79407946. https://doi.org/10.1021/ie400527b

49. Men'shova RV, Lepeshkin FD, Ermakova SP et al (2013) Effect of pretreatment conditions of brown algae by supercritical fluids on yield and structural characteristics of fucoidans. Chem Nat Compd 48:923-926. https://doi.org/10.1007/s10600-013-0429-z

50. Herrero M, Mendiola JA, Cifuentes A, Ibáñez E (2010) Supercritical fluid extraction: recent advances and applications. J Chromatogr A 1217:2495-2511

51. Edward R, Qiubai S, Zhiqiang Z et al (2009) Mini-review: green sustainable processes using supercritical fluid carbon dioxide. J Environ Sci 21:720-726. https://doi.org/10.1016/S10010742(08)62330-X

52. Zacconi FC, Cabrera AL FO-R-TJ of, 2017 U (2017) Isothermal solubility in supercritical carbon dioxide of solid derivatives of 2 , 3-dichloronaphthalene-1, 4-dione (dichlone): 2-(Benzylamino)-3. Elsevier, Amsterdam

53. Roodpeyma M, Guigard SE, Stiver WH (2018) Pressure control of a continuous pilot scale supercritical fluid extraction (SFE) process. J Supercrit Fluids 135:120-129. https://doi.org/10. 1016/j.supflu.2017.12.029

54. Kadam SU, Tiwari BK, O'Donnell CP (2013) Application of novel extraction technologies for bioactives from marine algae. J Agric Food Chem 61:4667-4675

55. Hanjabam MD, Kumar A, Tejpal CS et al (2019) Isolation of crude fucoidan from Sargassum wightii using conventional and ultra-sonication extraction methods. Bioact Carbohydrates Diet Fibre. https://doi.org/10.1016/j.bcdf.2019.100200

56. Alboofetileh M, Rezaei M, Tabarsa M, You SG (2019) Ultrasound-assisted extraction of sulfated polysaccharide from Nizamuddinia zanardinii: process optimization, structural 
characterization, and biological properties. J Food Process Eng. https://doi.org/10.1111/jfpe.12979

57. Alboofetileh M, Rezaei M, Tabarsa M et al (2019) Effect of different non-conventional extraction methods on the antibacterial and antiviral activity of fucoidans extracted from Nizamuddinia zanardinii. Int J Biol Macromol 124:131-137. https://doi. org/10.1016/j.ijbiomac.2018.11.201

58. Yan JK, Wang YY, Le MH, Bin WZ (2016) Ultrasonic effects on the degradation kinetics, preliminary characterization and antioxidant activities of polysaccharides from Phellinus linteus mycelia. Ultrason Sonochem 29:251-257. https://doi.org/10. 1016/j.ultsonch.2015.10.005

59. Garcia-Vaquero M, O'Doherty JV, Tiwari BK et al (2019) Enhancing the extraction of polysaccharides and antioxidants from macroalgae using sequential hydrothermal-assisted extraction followed by ultrasound and thermal technologies. Mar Drugs. https://doi.org/10.3390/md17080457

60. Santagata G, Grillo G, Immirzi B, et al (2018) Non-conventional ultrasound-assisted extraction of alginates from sargassum seaweed: from coastal waste to a novel polysaccharide source. In: Proceedings of the international conference on microplastic pollution in the mediterranean sea, pp 211-217

61. Hariharasubramanian J, Baik OD, Singhal RS (2015) Ultrasound-assisted extraction (UAE) of polysaccharide from dried biomass of sargassum muticum. Trans ASABE 58:1363-1370. https://doi.org/10.13031/trans.58.10914

62. Flórez-Fernández N, López-García M, González-Muñoz MJ et al (2017) Ultrasound-assisted extraction of fucoidan from Sargassum muticum. J Appl Phycol 29:1553-1561. https://doi. org/10.1007/s10811-016-1043-9

63. Hmelkov AB, Zvyagintseva TN, Shevchenko NM et al (2018) Ultrasound-assisted extraction of polysaccharides from brown alga Fucus evanescens. Structure and biological activity of the new fucoidan fractions. J Appl Phycol 30:2039-2046. https:// doi.org/10.1007/s10811-017-1342-9

64. Nie J, Chen D, Lu Y (2020) Deep eutectic solvents based ultrasonic extraction of polysaccharides from edible brown Seaweed Sargassum horneri. J Mar Sci Eng. https://doi.org/10. 3390/JMSE8060440

65. Garcia-Vaquero M, Rajauria G, Tiwari B et al (2018) Extraction and yield optimisation of fucose, glucans and associated antioxidant activities from laminaria digitata by applying response surface methodology to high intensity ultrasoundassisted extraction. Mar Drugs. https://doi.org/10.3390/md160 80257

66. Vázquez-Rodríguez B, Gutiérrez-Uribe JA, Antunes-Ricardo $M$ et al (2020) Ultrasound-assisted extraction of phlorotannins and polysaccharides from Silvetia compressa (Phaeophyceae). J Appl Phycol 32:1441-1453. https://doi.org/10.1007/ s10811-019-02013-2

67. Rahimi F, Tabarsa M, Rezaei M (2016) Ulvan from green algae Ulva intestinalis: optimization of ultrasound-assisted extraction and antioxidant activity. J Appl Phycol 28:2979-2990. https:// doi.org/10.1007/s 10811-016-0824-5

68. Kurd F, Samavati V (2015) Water soluble polysaccharides from Spirulina platensis: extraction and in vitro anti-cancer activity. Int J Biol Macromol 74:498-506. https://doi.org/10.1016/j. ijbiomac.2015.01.005

69. Kaufmann B, Christen P (2002) Recent extraction techniques for natural products: microwave-assisted extraction and pressurised solvent extraction. Phytochem Anal 13:105-113. https://doi.org/10.1002/pca.631

70. Richter BE, Jones BA, Ezzell JL et al (1996) Accelerated solvent extraction: a technique for sample preparation. Anal Chem 68:1033-1039. https://doi.org/10.1021/ac9508199
71. Wu S-C (2017) Antioxidant activity of sulfated seaweeds polysaccharides by novel assisted extraction. In: Xu Z (ed) Solubility of polysaccharides. In Tech, Singapore

72. Nieto A, Borrull F, Pocurull E, Marcé RM (2010) Pressurized liquid extraction: a useful technique to extract pharmaceuticals and personal-care products from sewage sludge. TrAC Trends Anal Chem 29:752-764

73. Dobrinčić A, Balbino S, Zorić Z et al (2020) Advanced technologies for the extraction of marine brown algal polysaccharides. Mar Drugs 18:168

74. Saravana PS, Cho YJ, Park YB et al (2016) Structural, antioxidant, and emulsifying activities of fucoidan from Saccharina japonica using pressurized liquid extraction. Carbohydr Polym 153:518-525. https://doi.org/10.1016/j.carbpol.2016.08.014

75. Santoyo S, Plaza M, Jaime L et al (2011) Pressurized liquids as an alternative green process to extract antiviral agents from the edible seaweed Himanthalia elongata. J Appl Phycol 23:909_ 917. https://doi.org/10.1007/s10811-010-9611-x

76. Saravana PS, Choi JH, Park YB et al (2016) Evaluation of the chemical composition of brown seaweed (Saccharina japonica) hydrolysate by pressurized hot water extraction. Algal Res 13:246-254. https://doi.org/10.1016/j.algal.2015.12.004

77. Saravana PS, Cho YN, Patil MP et al (2018) Hydrothermal degradation of seaweed polysaccharide: characterization and biological activities. Food Chem 268:179-187. https://doi.org/10. 1016/j.foodchem.2018.06.077

78. Saravana PS, Tilahun A, Gerenew C et al (2018) Subcritical water extraction of fucoidan from Saccharina japonica: optimization, characterization and biological studies. J Appl Phycol 30:579-590. https://doi.org/10.1007/s10811-017-1245-9

79. Vergara-Salinas JR, Cuevas-Valenzuela J, Pérez-Correa JR (2015) Pressurized hot water extraction of polyphenols from plant material. In: Gupta VK, Tuohy MG (eds) Biotechnology of bioactive compounds: sources and applications. Wiley, Chichester, pp 63-101

80. Alvarez-Rivera G, Bueno M, Ballesteros-Vivas D, et al (2019) Pressurized liquid extraction. In: Liquid-phase extraction. Elsevier, Amsterdam, pp 375-398

81. Mendes M, Carvalho AP, Magalhães JMCS et al (2016) Response surface evaluation of microwave-assisted extraction conditions for Lycium barbarum bioactive compounds. Innov Food Sci Emerg Technol 33:319-326. https://doi.org/10.1016/j. ifset.2015.12.025

82. Gilbert-López B, Barranco A, Herrero M et al (2017) Development of new green processes for the recovery of bioactives from Phaeodactylum tricornutum. Food Res Int 99:1056-1065. https:// doi.org/10.1016/j.foodres.2016.04.022

83. Ma CH, Yang L, Zu YG, Liu TT (2012) Optimization of conditions of solvent-free microwave extraction and study on antioxidant capacity of essential oil from Schisandra chinensis (Turcz.) Baill. Food Chem 134:2532-2539. https://doi.org/10.1016/j. foodchem.2012.04.080

84. Wang S-Y, Yang L, Yuan-Gang Z et al (2011) Design and performance evaluation of ionic-liquids-based microwave-assisted environmentally friendly extraction technique for camptothecin and 10-hydroxycamptothecin from Samara of Camptotheca acuminata. Ind Eng Chem Res 50:13620-13627. https://doi.org/ 10.1021/ie201370m

85. Cao C, Huang Q, Zhang B et al (2018) Physicochemical characterization and in vitro hypoglycemic activities of polysaccharides from Sargassum pallidum by microwave-assisted aqueous twophase extraction. Int J Biol Macromol 109:357-368. https://doi. org/10.1016/j.ijbiomac.2017.12.096

86. Boulho R, Marty C, Freile-Pelegrín Y et al (2017) Antiherpetic (HSV-1) activity of carrageenans from the red seaweed Solieria chordalis (Rhodophyta, Gigartinales) extracted 
by microwave-assisted extraction (MAE). J Appl Phycol 29:2219-2228

87. Le B, Golokhvast KS, Yang SH, Sun S (2019) Optimization of microwave-assisted extraction of polysaccharides from Ulva pertusa and evaluation of their antioxidant activity. Antioxidant. https://doi.org/10.3390/antiox8050129

88. Chen YY, Xue YT (2019) Optimization of microwave assisted extraction, chemical characterization and antitumor activities of polysaccharides from porphyra haitanensis. Carbohydr Polym 206:179-186. https://doi.org/10.1016/j.carbpol.2018. 10.093

89. Ren B, Chen C, Li C et al (2017) Optimization of microwaveassisted extraction of Sargassum thunbergii polysaccharides and its antioxidant and hypoglycemic activities. Carbohydr Polym 173:192-201. https://doi.org/10.1016/j.carbpol.2017.05.094

90. Shang X, Chu D, Zhang J et al (2021) Microwave-assisted extraction, partial purification and biological activity in vitro of polysaccharides from bladder-wrack (Fucus vesiculosus) by using deep eutectic solvents. Sep Purif Technol. https://doi.org/10. 1016/j.seppur.2020.118169

91. Alam MA, Sarker MZI, Ghafoor K et al (2017) Bioactive compounds and extraction techniques. In: Nguyen VT (ed) Recovering bioactive compounds from agricultural wastes. Wiley, Chichester, pp 33-53

92. Fleurence J, Massiani L, Guyader O, Mabeau S (1995) Use of enzymatic cell wall degradation for improvement of protein extraction from Chondrus crispus, Gracilaria verrucosa and Palmaria palmata. J Appl Phycol 7:393-397. https://doi.org/10. 1007/BF00003796

93. Shen L, Wang X, Wang Z et al (2008) Studies on tea protein extraction using alkaline and enzyme methods. Food Chem 107:929-938. https://doi.org/10.1016/j.foodchem.2007.08.047

94. Michalak I, Chojnacka K (2014) Algal extracts: technology and advances. Eng Life Sci 14:581-591

95. Kang SM, Kim KN, Lee SH et al (2011) Anti-inflammatory activity of polysaccharide purified from AMG-assistant extract of Ecklonia cava in LPS-stimulated RAW 264.7 macrophages. Carbohydr Polym 85:80-85. https://doi.org/10.1016/j.carbpol. 2011.01.052

96. Heo SJ, Park EJ, Lee KW, Jeon YJ (2005) Antioxidant activities of enzymatic extracts from brown seaweeds. Bioresour Technol 96:1613-1623. https://doi.org/10.1016/j.biortech.2004.07.013

97. Alboofetileh M, Rezaei M, Tabarsa M (2019) Enzyme-assisted extraction of Nizamuddinia zanardinii for the recovery of sulfated polysaccharides with anticancer and immune-enhancing activities. J Appl Phycol 31:1391-1402. https://doi.org/10.1007/ s10811-018-1651-7

98. Nguyen TT, Mikkelsen MD, Nguyen Tran VH et al (2020) Enzyme-assisted fucoidan extraction from brown macroalgae fucus distichus subsp. Evanescens and saccharina latissima. Mar Drugs. https://doi.org/10.3390/md18060296

99. Fournière M, Latire T, Lang M et al (2019) Production of active poly- and oligosaccharidic fractions from ulva sp. by combining enzyme-assisted extraction (EAE) and depolymerization. Metabolites 9:182. https://doi.org/10.3390/metabo9090182

100. Puri M, Sharma D, Barrow CJ (2012) Enzyme-assisted extraction of bioactives from plants. Trends Biotechnol 30:37-44

101. Latif S, Anwar F (2009) Physicochemical studies of hemp (Cannabis sativa) seed oil using enzyme-assisted cold-pressing. Eur J Lipid Sci Technol 111:1042-1048. https://doi.org/10.1002/ejlt. 200900008

102. Turgut Dunford N, Brian Dunford H (2004) Nutritionally enhanced edible oil processing. AOCS Publishing, Champaign

103. Bhattacharjee P, Singhal RS, Tiwari SR (2007) Supercritical carbon dioxide extraction of cottonseed oil. J Food Eng 79:892-898. https://doi.org/10.1016/j.jfoodeng.2006.03.009
104. Hammed AM, Jaswir I, Simsek S et al (2017) Enzyme aided extraction of sulfated polysaccharides from Turbinaria turbinata brown seaweed. Int Food Res J 24:1660-1666

105. Li H, Yu X, Jin Y et al (2008) Development of an eco-friendly agar extraction technique from the red seaweed Gracilaria lemaneiformis. Bioresour Technol 99:3301-3305. https://doi.org/10. 1016/j.biortech.2007.07.002

106. Rodrigues D, Freitas AC, Queirós R et al (2017) Bioactive polysaccharides extracts from Sargassum muticum by high hydrostatic pressure. J Food Process Preserv. https://doi.org/10.1111/ jfpp. 12977

107. Vauchel P, Kaas R, Arhaliass A et al (2008) A new process for extracting alginates from Laminaria digitata: reactive extrusion. Food Bioprocess Technol 1:297-300. https://doi.org/10.1007/ s11947-008-0082-x

108. Khawli FA, Pateiro M, Domínguez R et al (2019) Innovative green technologies of intensification for valorization of seafood and their by-products. Mar Drugs 17:689

109. Medina-Torres N, Ayora-Talavera T, Espinosa-Andrews $\mathrm{H}$ et al (2017) Ultrasound assisted extraction for the recovery of phenolic compounds from vegetable sources. Agronomy. https://doi. org/10.3390/agronomy7030047

110. Chemat F, Rombaut N, Sicaire AG et al (2017) Ultrasound assisted extraction of food and natural products. Mechanisms, techniques, combinations, protocols and applications. A review. Ultrason Sonochem 34:540-560

111. Abdul Khalil HPS, Lai TK, Tye YY et al (2018) A review of extractions of seaweed hydrocolloids: properties and applications. Express Polym Lett 12:296-317. https://doi.org/10.3144/ expresspolymlett.2018.27

112. Lorbeer AJ, Lahnstein J, Fincher GB et al (2015) Kinetics of conventional and microwave-assisted fucoidan extractions from the brown alga, Ecklonia radiata. J Appl Phycol 27:2079-2087. https://doi.org/10.1007/s10811-014-0446-8

113. Rodriguez-Jasso RM, Mussatto SI, Pastrana L et al (2011) Microwave-assisted extraction of sulfated polysaccharides (fucoidan) from brown seaweed. Carbohydr Polym 86:1137-1144. https:// doi.org/10.1016/j.carbpol.2011.06.006

114. Xiao Q, Weng H, Ni H et al (2019) Physicochemical and gel properties of agar extracted by enzyme and enzyme-assisted methods. Food Hydrocoll 87:530-540. https://doi.org/10.1016/j. foodhyd.2018.08.041

115. Cheng X, Bi L, Zhao Z, Chen Y (2015) Advances in Enzyme Assisted Extraction of Natural Products. In: atlantis-press.com

116. Li H, Huang J, Xin Y et al (2009) Optimization and scale-up of a new photobleaching agar extraction process from Gracilaria lemaneiformis. J Appl Phycol 21:247-254. https://doi.org/10. 1007/s10811-008-9358-9

117. Benchamas G, Huang S, Huang G (2020) The influence of traditional and new processing technologies on the structure and function of food polysaccharide. Food Funct 11:5718-5725

118. Chakraborty M, Miao C, McDonald A, Chen S (2012) Concomitant extraction of bio-oil and value added polysaccharides from Chlorella sorokiniana using a unique sequential hydrothermal extraction technology. Fuel 95:63-70. https://doi.org/10.1016/j. fuel.2011.10.055

119. Cantu-Jungles TM, De Almeida CP, Iacomini M et al (2015) Arabinan-rich pectic polysaccharides from buriti (Mauritia flexuosa): an Amazonian edible palm fruit. Carbohydr Polym 122:276-281. https://doi.org/10.1016/j.carbpol.2014.12.085

120. Sevag MG, Lackman DB, Smolens J (1938) The isolation of the components of streptococcal nucleoproteins in serologically active form. J Biol Chem 124:425-436. https://doi.org/10.1016/ s0021-9258(18)74048-9

121. Lim SJ, Wan Aida WM (2017) Extraction of sulfated polysaccharides (Fucoidan) from brown seaweed. In: Venkatesan J et al 
(eds) Seaweed polysaccharides: isolation, biological and biomedical applications. Elsevier, Amsterdam, pp 27-46

122. Peng Z, Liu M, Fang Z et al (2012) Composition and cytotoxicity of a novel polysaccharide from brown alga (Laminaria japonica). Carbohydr Polym 89:1022-1026. https://doi.org/10.1016/j.carbp ol.2012.03.043

123. Yu Y, Li Y, Du C et al (2017) Compositional and structural characteristics of sulfated polysaccharide from Enteromorpha prolifera. Carbohydr Polym 165:221-228. https://doi.org/10.1016/j. carbpol.2017.02.011

124. Patel AK, Laroche C, Marcati A et al (2013) Separation and fractionation of exopolysaccharides from Porphyridium cruentum. Bioresour Technol 145:345-350. https://doi.org/10.1016/j.biort ech.2012.12.038

125. Xie JH, Shen MY, Nie SP et al (2014) Separation of water-soluble polysaccharides from Cyclocarya paliurus by ultrafiltration process. Carbohydr Polym 101:479-483. https://doi.org/10. 1016/j.carbpol.2013.09.075

126. Shi L (2016) Bioactivities, isolation and purification methods of polysaccharides from natural products: a review. Int J Biol Macromol 92:37-48. https://doi.org/10.1016/j.ijbiomac.2016.06. 100

127. Müller MB, Schmitt D, Frimmel FH (2000) Fractionation of natural organic matter by size exclusion chromatography-properties and stability of fractions. Environ Sci Technol 34:48674872. https://doi.org/10.1021/es000076v

128. Markwell J (2009) Fundamental laboratory approaches for biochemistry and biotechnology, 2nd edition. Biochem Mol Biol Educ 37:317-318. https://doi.org/10.1002/bmb.20321

129. Khan BM, Cheong KL, Liu Y (2020) Advances in separation and purification of bioactive polysaccharides through high-speed counter-current chromatography Perovskite quantum dots and its application view project biochemical and in vitro investigation of Acorus calamus for its pharmacological importance and conservation view project. Artic J Chromatogr Sci. https://doi.org/ 10.1093/chromsci/bmaa063

130. Yang Y, Khan BM, Zhang X et al (2020) Advances in separation and purification of bioactive polysaccharides through high-speed counter-current chromatography. J Chromatogr Sci 58:992-1000. https://doi.org/10.1093/chromsci/bmaa063

131. Schwartz L (2003) Diafiltration: A Fast, Efficient Method for Desalting or Buffer Exchange of Biological Samples. Pall Sci Tech Rep 6

132. Bonnélye V, Guey L, Del Castillo J (2008) UF/MF as RO pretreatment: the real benefit. Desalination 222:59-65. https://doi. org/10.1016/j.desal.2007.01.129

133. Tang L, Chen Y, Jiang Z et al (2017) Purification, partial characterization and bioactivity of sulfated polysaccharides from Grateloupia livida. Int J Biol Macromol 94:642-652. https://doi.org/ 10.1016/j.ijbiomac.2016.10.067

134. Sun Y, Gong G, Guo Y et al (2018) Purification, structural features and immunostimulatory activity of novel polysaccharides from Caulerpa lentillifera. Int J Biol Macromol 108:314-323. https://doi.org/10.1016/j.ijbiomac.2017.12.016

135. Li Y, Qin G, Cheng C et al (2020) Purification, characterization and anti-tumor activities of polysaccharides from Ecklonia kurome obtained by three different extraction methods. Int J Biol Macromol 150:1000-1010. https://doi.org/10.1016/j.ijbiomac. 2019.10.216

136. Bahramzadeh S, Tabarsa M, You SG et al (2019) Purification, structural analysis and mechanism of murine macrophage cell activation by sulfated polysaccharides from Cystoseira indica. Carbohydr Polym 205:261-270. https://doi.org/10.1016/j.carbp ol.2018.10.022

137. Balti R, Le Balc'h R, Brodu N et al (2018) Concentration and purification of Porphyridium cruentum exopolysaccharides by membrane filtration at various cross-flow velocities. Process Biochem 74:175-184. https://doi.org/10.1016/j.procbio.2018. 06.021

138. Di T, Chen G, Sun Y et al (2017) Antioxidant and immunostimulating activities in vitro of sulfated polysaccharides isolated from Gracilaria rubra. J Funct Foods 28:64-75. https://doi.org/10. 1016/j.jff.2016.11.005

139. Song H, He M, Gu C et al (2018) Extraction optimization, purification, antioxidant activity, and preliminary structural characterization of crude polysaccharide from an arctic Chlorella sp. Polymers (Basel). https://doi.org/10.3390/polym10030292

140. Zhang B, Li Y, Zhang F et al (2020) Extraction, structure and bioactivities of the polysaccharides from Pleurotus eryngii: a review. Int J Biol Macromol 150:1342-1347

141. Rajauria G, Ravindran R, Garcia-Vaquero M et al (2021) Molecular characteristics and antioxidant activity of laminarin extracted from the seaweed species Laminaria hyperborea, using hydrothermal-assisted extraction and a multi-step purification procedure. Food Hydrocoll. https://doi.org/10.1016/j.foodhyd.2020. 106332

142. Hentati F, Delattre C, Gardarin C et al (2020) Structural features and rheological properties of a sulfated Xylogalactan-rich fraction isolated from Tunisian red seaweed Jania adhaerens. Appl Sci. https://doi.org/10.3390/app10051655

143. Belattmania Z, Kaidi S, El AS et al (2020) Isolation and FTIRATR and $1 \mathrm{H}$ NMR characterization of alginates from the main alginophyte species of the atlantic coast of Morocco. Molecules. https://doi.org/10.3390/molecules25184335

144. Yang Y, Hu T, Li J et al (2021) Structural characterization and effect on leukopenia of fucoidan from Durvillaea antarctica. Carbohydr Polym. https://doi.org/10.1016/j.carbpol.2020.117529

145. Wahlström N, Edlund U, Pavia H et al (2020) Cellulose from the green macroalgae Ulva lactuca: isolation, characterization, optotracing, and production of cellulose nanofibrils. Cellulose 27:3707-3725. https://doi.org/10.1007/s10570-020-03029-5

146. El-Naggar NEA, Hussein MH, Shaaban-Dessuuki SA, Dalal SR (2020) Production, extraction and characterization of Chlorella vulgaris soluble polysaccharides and their applications in AgNPs biosynthesis and biostimulation of plant growth. Sci Rep. https:// doi.org/10.1038/s41598-020-59945-w

147. Mukherjee S, Ghosh K, Hahn F et al (2019) Chemically sulfated polysaccharides from natural sources: assessment of extractionsulfation efficiencies, structural features and antiviral activities. Int J Biol Macromol 136:521-530. https://doi.org/10.1016/j.ijbio mac.2019.05.005

148. Faccin-Galhardi LC, Ray S, Lopes N et al (2019) Assessment of antiherpetic activity of nonsulfated and sulfated polysaccharides from Azadirachta indica. Int J Biol Macromol 137:54-61. https:// doi.org/10.1016/j.ijbiomac.2019.06.129

149. Ray B, Schütz M, Mukherjee S et al (2021) Exploiting the amazing diversity of natural source-derived polysaccharides: modern procedures of isolation, engineering, and optimization of antiviral activities. Polymers (Basel) 13:1-22

150. Faccin-Galhardi LC, Aimi Yamamoto K, Ray S et al (2012) The in vitro antiviral property of Azadirachta indica polysaccharides for poliovirus. J Ethnopharmacol 142:86-90. https://doi.org/10. 1016/j.jep.2012.04.018

151. Yu Y, Shen M, Song Q, Xie J (2018) Biological activities and pharmaceutical applications of polysaccharide from natural resources: a review. Carbohydr Polym 183:91-101

152. Sun Y, Chen X, Song L et al (2018) Antiviral activity against avian leucosis virus subgroup $\mathrm{j}$ of degraded polysaccharides from Ulva pertusa. Biomed Res Int. https://doi.org/10.1155/2018/ 9415965

153. Sun Y, Chen X, Cheng Z et al (2017) Degradation of polysaccharides from Grateloupia filicina and their antiviral activity to 
avian leucosis virus subgroup. J Mar Drugs. https://doi.org/10. 3390/md15110345

154. Cao Y, Hao Y, Li Z et al (2016) Antiviral activity of polysaccharide extract from Laminaria japonica against respiratory syncytial virus. Biomed Pharmacother 84:1705-1710. https://doi.org/ 10.1016/j.biopha.2016.10.082

155. Wang S, Wang W, Hou L et al (2020) A sulfated glucuronorhamnan from the green seaweed Monostroma nitidum: characteristics of its structure and antiviral activity. Carbohydr Polym. https:// doi.org/10.1016/j.carbpol.2019.115280

156. Hidari KIPJ, Takahashi N, Arihara M et al (2008) Structure and anti-dengue virus activity of sulfated polysaccharide from a marine alga. Biochem Biophys Res Commun 376:91-95. https:// doi.org/10.1016/j.bbrc.2008.08.100

157. Queiroz KCS, Medeiros VP, Queiroz LS et al (2008) Inhibition of reverse transcriptase activity of HIV by polysaccharides of brown algae. Biomed Pharmacother 62:303-307. https://doi.org/ 10.1016/j.biopha.2008.03.006

158. Komatsu T, Kido N, Sugiyama T, Yokochi T (2013) Antiviral activity of acidic polysaccharides from Coccomyxa gloeobotrydiformi, a green alga, against an in vitro human influenza A virus infection. Immunopharmacol Immunotoxicol 35:1-7. https://doi. org/10.3109/08923973.2012.710636

159. Lee JB, Hayashi K, Hirata M et al (2006) Antiviral sulfated polysaccharide from Navicula directa, a diatom collected from deep-sea water in Toyama Bay. Biol Pharm Bull 29:2135-2139. https://doi.org/10.1248/bpb.29.2135

160. Talarico LB, Pujol CA, Zibetti RGM et al (2005) The antiviral activity of sulfated polysaccharides against dengue virus is dependent on virus serotype and host cell. Antiviral Res 66:103110. https://doi.org/10.1016/j.antiviral.2005.02.001

161. Yu Y, Zhang Y, Hu C et al (2019) Chemistry and immunostimulatory activity of a polysaccharide from Undaria pinnatifida. Food Chem Toxicol 128:119-128. https://doi.org/10.1016/j.fct. 2019.03.042

162. Qi J, Kim SM (2017) Characterization and immunomodulatory activities of polysaccharides extracted from green alga Chlorella ellipsoidea. Int J Biol Macromol 95:106-114. https://doi.org/10. 1016/j.ijbiomac.2016.11.039

163. Hao H, Han Y, Yang L et al (2019) Structural characterization and immunostimulatory activity of a novel polysaccharide from green alga Caulerpa racemosa var peltata. Int J Biol Macromol 134:891-900. https://doi.org/10.1016/j.ijbiomac.2019.05.084

164. Tian H, Liu H, Song W et al (2020) Structure, antioxidant and immunostimulatory activities of the polysaccharides from Sargassum carpophyllum. Algal Res. https://doi.org/10.1016/j.algal. 2020.101853

165. Han Y, Wu Y, Li G et al (2020) Structural characterization and transcript-metabolite correlation network of immunostimulatory effects of sulfated polysaccharides from green alga Ulva pertusa. Food Chem. https://doi.org/10.1016/j.foodchem.2020.128537

166. Tabarsa M, You SG, Dabaghian EH, Surayot U (2018) Watersoluble polysaccharides from Ulva intestinalis: molecular properties, structural elucidation and immunomodulatory activities. J Food Drug Anal 26:599-608. https://doi.org/10.1016/j.jfda.2017. 07.016

167. Bray F, Ferlay J, Soerjomataram I et al (2018) Global cancer statistics 2018: GLOBOCAN estimates of incidence and mortality worldwide for 36 cancers in 185 countries. CA Cancer J Clin 68:394-424. https://doi.org/10.3322/caac.21492

168. Khan T, Date A, Chawda H, Patel K (2019) Polysaccharides as potential anticancer agents-a review of their progress. Carbohydr Polym 210:412-428

169. Vaikundamoorthy R, Krishnamoorthy V, Vilwanathan R, Rajendran R (2018) Structural characterization and anticancer activity (MCF7 and MDA-MB-231) of polysaccharides fractionated from brown seaweed Sargassum wightii. Int J Biol Macromol 111:1229-1237. https://doi.org/10.1016/j.ijbiomac.2018.01.125

170. Usoltseva RV, Anastyuk SD, Shevchenko NM et al (2017) Polysaccharides from brown algae Sargassum duplicatum: the structure and anticancer activity in vitro. Carbohydr Polym 175:547556. https://doi.org/10.1016/j.carbpol.2017.08.044

171. Usoltseva RV, Shevchenko NM, Malyarenko OS et al (2018) Structure and anticancer activity of native and modified polysaccharides from brown alga Dictyota dichotoma. Carbohydr Polym 180:21-28. https://doi.org/10.1016/j.carbpol.2017.10.006

172. Usoltseva RV, Anastyuk SD, Ishina IA et al (2018) Structural characteristics and anticancer activity in vitro of fucoidan from brown alga Padina boryana. Carbohydr Polym 184:260-268. https://doi.org/10.1016/j.carbpol.2017.12.071

173. Gheda S, El-Sheekh M, Abou-Zeid A (2018) In vitro anticancer activity of polysaccharide extracted from red alga Jania rubens against breast and colon cancer cell lines. Asian Pac J Trop Med 11:583-589. https://doi.org/10.4103/1995-7645.244523

174. Malyarenko OS, Usoltseva RV, Shevchenko NM et al (2017) In vitro anticancer activity of the laminarans from Far Eastern brown seaweeds and their sulfated derivatives. J Appl Phycol 29:543-553. https://doi.org/10.1007/s10811-016-0915-3

175. Chen X, Song L, Wang H et al (2019) Partial characterization, the immune modulation and anticancer activities of sulfated polysaccharides from filamentous microalgae Tribonema sp. Molecules. https://doi.org/10.3390/molecules24020322

176. Yao WZ, Veeraperumal S, Qiu HM et al (2020) Anti-cancer effects of Porphyra haitanensis polysaccharides on human colon cancer cells via cell cycle arrest and apoptosis without causing adverse effects in vitro. Biotech 10:12. https://doi.org/10.1007/ s13205-020-02379-y

177. Anastyuk SD, Shevchenko NM, Ermakova SP et al (2012) Anticancer activity in vitro of a fucoidan from the brown alga Fucus evanescens and its low-molecular fragments, structurally characterized by tandem mass-spectrometry. Carbohydr Polym 87:186-194. https://doi.org/10.1016/j.carbpol.2011.07.036

178. Jin W, Zhang W, Liu G et al (2017) The structure-activity relationship between polysaccharides from Sargassum thunbergii and anti-tumor activity. Int J Biol Macromol 105:686-692. https://doi.org/10.1016/j.ijbiomac.2017.07.089

179. Saeedi P, Petersohn I, Salpea P et al (2019) Global and regional diabetes prevalence estimates for 2019 and projections for 2030 and 2045: Results from the International Diabetes Federation Diabetes Atlas, 9th edition. Diabetes Res Clin Pract 157:107. https://doi.org/10.1016/j.diabres.2019.107843

180. Jia RB, Wu J, Li ZR et al (2020) Comparison of physicochemical properties and antidiabetic effects of polysaccharides extracted from three seaweed species. Int J Biol Macromol 149:81-92. https://doi.org/10.1016/j.ijbiomac.2020.01.111

181. Makkar F, Chakraborty K (2017) Antidiabetic and anti-inflammatory potential of sulphated polygalactans from red seaweeds Kappaphycus alvarezii and Gracilaria opuntia. Int J Food Prop 20:1326-1337. https://doi.org/10.1080/10942912.2016.1209216

182. Koh HSA, Lu J, Zhou W (2020) Structural dependence of sulfated polysaccharide for diabetes management: fucoidan from Undaria pinnatifida inhibiting $\alpha$-glucosidase more strongly than $\alpha$-amylase and amyloglucosidase. Front Pharmacol. https://doi. org/10.3389/fphar.2020.00831

183. Yang C, Chen Y, Chen M et al (2017) The antidiabetic activity of brown seaweed sargassum confusum polysaccharide hydrolysates in insulin resistance HepG2 cells in vitro. Res J Biotechnol 12:1-9

184. Zhong QW, Zhou TS, Qiu WH et al (2021) Characterization and hypoglycemic effects of sulfated polysaccharides derived from brown seaweed Undaria pinnatifida. Food Chem. https://doi.org/ 10.1016/j.foodchem.2020.128148 
185. Mohan K, Muralisankar T, Uthayakumar V et al (2020) Trends in the extraction, purification, characterisation and biological activities of polysaccharides from tropical and sub-tropical fruits - A comprehensive review. Carbohydr Polym 238:116185

186. Fimbres-Olivarria D, Carvajal-Millan E, Lopez-Elias JA et al (2018) Chemical characterization and antioxidant activity of sulfated polysaccharides from Navicula sp. Food Hydrocoll 75:229-236. https://doi.org/10.1016/j.foodhyd.2017.08.002

187. Jaballi I, Sallem I, Feki A et al (2019) Polysaccharide from a Tunisian red seaweed Chondrus canaliculatus: structural characteristics, antioxidant activity and in vivo hemato-nephroprotective properties on maneb induced toxicity. Int J Biol Macromol 123:1267-1277. https://doi.org/10.1016/j.ijbiomac.2018.12.048

188. Khan BM, Qiu HM, Xu SY et al (2020) Physicochemical characterization and antioxidant activity of sulphated polysaccharides derived from Porphyra haitanensis. Int J Biol Macromol 145:1155-1161. https://doi.org/10.1016/j.ijbiomac.2019.10.040

189. Palanisamy $S$, Vinosha M, Marudhupandi $T$ et al (2017) In vitro antioxidant and antibacterial activity of sulfated polysaccharides isolated from Spatoglossum asperum. Carbohydr Polym 170:296-304. https://doi.org/10.1016/j.carbpol.2017.04.085

190. Hentati F, Delattre C, Ursu AV et al (2018) Structural characterization and antioxidant activity of water-soluble polysaccharides from the Tunisian brown seaweed Cystoseira compressa. Carbohydr Polym 198:589-600. https://doi.org/10.1016/j.carbpol. 2018.06.098

191. Shanura Fernando IP, Asanka Sanjeewa KK, Samarakoon KW et al (2017) FTIR characterization and antioxidant activity of water soluble crude polysaccharides of Sri Lankan marine algae. Algae 32:75-86. https://doi.org/10.4490/algae.2017.32.12.1

192. Zhong Q, Wei B, Wang S et al (2019) The antioxidant activity of polysaccharides derived from marine organisms: an overview. Mar Drugs 17:674

193. Taniguchi M, Kuda T, Shibayama J et al (2019) In vitro antioxidant, anti-glycation and immunomodulation activities of fermented blue-green algae Aphanizomenon flos-aquae. Mol Biol Rep 46:1775-1786. https://doi.org/10.1007/s11033-019-04628-7

194. Sun Y, Liu Z, Song S et al (2020) Anti-inflammatory activity and structural identification of a sulfated polysaccharide CLGP4 from Caulerpa lentillifera. Int J Biol Macromol 146:931-938. https:// doi.org/10.1016/j.ijbiomac.2019.09.216

195. He X, Yamauchi A, Nakano T et al (2019) The composition and anti-inflammatory effect of polysaccharides from the red alga Chondrus verrucosus. Fish Sci 85:859-865. https://doi.org/10. 1007/s12562-019-01336-w

196. Wang L, Oh JY, Jayawardena TU et al (2020) Anti-inflammatory and anti-melanogenesis activities of sulfated polysaccharides isolated from Hizikia fusiforme: short communication. Int J Biol Macromol 142:545-550. https://doi.org/10.1016/j.ijbiomac.2019. 09.128

197. Costa LEC, Brito TV, Damasceno ROS et al (2020) Chemical structure, anti-inflammatory and antinociceptive activities of a sulfated polysaccharide from Gracilaria intermedia algae. Int J Biol Macromol 159:966-975. https://doi.org/10.1016/j.ijbiomac. 2020.05.166

198. Mirzadeh M, Arianejad MR, Khedmat L (2020) Antioxidant, antiradical, and antimicrobial activities of polysaccharides obtained by microwave-assisted extraction method: a review. Carbohydr. Polym. 229:115421

199. Vishwakarma J, Vavilala SL (2019) Evaluating the antibacterial and antibiofilm potential of sulphated polysaccharides extracted from green algae Chlamydomonas reinhardtii. J Appl Microbiol 127:1004-1017. https://doi.org/10.1111/jam.14364

200. Adrien A, Bonnet A, Dufour D et al (2019) Anticoagulant activity of sulfated ulvan isolated from the green macroalga ulva rigida. Mar Drugs. https://doi.org/10.3390/md17050291
201. Venkatesan M, Arumugam V, Pugalendi R et al (2019) Antioxidant, anticoagulant and mosquitocidal properties of water soluble polysaccharides (WSPs) from Indian seaweeds. Process Biochem 84:196-204. https://doi.org/10.1016/j.procbio.2019.05.029

202. Cao S, He X, Qin L et al (2019) Anticoagulant and antithrombotic properties in vitro and in vivo of a novel sulfated polysaccharide from marine green alga Monostroma nitidum. Mar Drugs. https://doi.org/10.3390/md17040247

203. Lekshmi V, Kurup GM (2019) Anticoagulant activities of sulfated polysaccharides from the edible marine algae Padina tetrastromatica and Ulva fasciata: a combined in vitro and in vivo approach. J Pharmacogn Phytochem 8:693-698

204. da Chagas FD, Lima GC, dos Santos VIN, et al (2020) Sulfated polysaccharide from the red algae Gelidiella acerosa: anticoagulant, antiplatelet and antithrombotic effects. Int J Biol Macromol 159:415-421. https://doi.org/10.1016/j.ijbiomac.2020.05.012

205. Chen Y, Liu X, Wu L et al (2018) Physicochemical characterization of polysaccharides from Chlorella pyrenoidosa and its antiageing effects in Drosophila melanogaster. Carbohydr Polym 185:120-126. https://doi.org/10.1016/j.carbpol.2017.12.077

206. Jesumani V, Du H, Pei P et al (2019) Unravelling property of polysaccharides from Sargassum sp. as an anti-wrinkle and skin whitening property. Int J Biol Macromol 140:216-224. https:// doi.org/10.1016/j.ijbiomac.2019.08.027

207. Fernando IPS, Sanjeewa KKA, Samarakoon KW et al (2018) The potential of fucoidans from Chnoospora minima and Sargassum polycystum in cosmetics: antioxidant, anti-inflammatory, skin-whitening, and antiwrinkle activities. J Appl Phycol 30:3223-3232

208. Kolsi RBA, Jardak N, Hajkacem F et al (2017) Anti-obesity effect and protection of liver-kidney functions by Codium fragile sulphated polysaccharide on high fat diet induced obese rats. Int $\mathrm{J}$ Biol Macromol 102:119-129. https://doi.org/10.1016/j.ijbiomac. 2017.04.017

209. Yang T-H, Chiu C-Y, Lu T-J et al (2019) The anti-obesity effect of polysaccharide-rich red algae (Gelidium amansii) hot-water extracts in high-fat diet-induced obese hamsters. Mar Drugs. https://doi.org/10.3390/md17090532

210. Xuwang C (2017) The preparation method of algal polysaccharides extract. Google patents.

211. Guanqing W, Baihong L, Jianqiang L and Huawei Y (2020) Process for producing, separating and purifying algal polysaccharide. Google patents.

212. Yan S (2020) Method for removing impurity protein in crude seaweed polysaccharide. Google patents.

213. Pengcheng L (2019) A kind of application of algal polysaccharides. Google patents.

214. El R (2013) Method of enzyme cleavage of polysaccharides derived from algae. Google patents.

215. Xiaolin C (2014) Application of algal polysaccharide. Google patents.

216. Hongmei G (2019) A kind of preparation and application containing algal polysaccharides and fulvic acid composite synergistic phosphate fertilizer. Google patents.

217. Wen $Z$ (2018) A kind of method for extracting fucoidan from sea-tangle using ultrasonic wave. Google patents.

218. Riming H (2021) Rapid screening method and application of immune regulation activity of algal polysaccharide. Google patents.

219. Zhiyun D (2020) Application of algal polysaccharide and derivatives thereof in the preparation of medicine for preventing and/ or treating novel coronavirus infection. Google patents.

220. Shu-liang S (2017) The new technology of fucoidan is extracted in a kind of waste liquid from kelp processing. Google patents.

221. Honghao $\mathrm{H}$ (2020) Medicine composition for treating lung cancer and preparation method thereof. Google patents. 
222. Xiang Z (2019) The application and method of fucoidan and its hydrolysis oligosaccharides in preparation probiotics protective agent. Google patents.

223. Fang W (2017) A kind of method for improving seaweed polysaccharide sulfate recovery rate. Google patents.
224. Zheng T (2021) Ting Composition with anti-ageing effect and preparation method and application thereof. Google patents.

Publisher's Note Springer Nature remains neutral with regard to jurisdictional claims in published maps and institutional affiliations.

\section{Authors and Affiliations}

\section{Sonal Nigam ${ }^{1} \cdot$ Rachana Singh $^{2} \cdot$ Sheetal Kaushik Bhardwaj ${ }^{3} \cdot$ Rokkayya Sami $^{4} \cdot$ Maria P. Nikolova $^{5}$. Murthy Chavali ${ }^{6} \cdot$ Surbhi Sinha ${ }^{2}$ (I)}

1 Amity Institute of Microbial Technology, Amity University, Sector 125, Noida 201 313, Uttar Pradesh, India

2 Amity Institute of Biotechnology, Amity University, Sector 125, Noida 201313, Uttar Pradesh, India

3 Vant Hoff Institute for Molecular Sciences, University of Amsterdam, Science Park 904, 1098 XH Amsterdam, the Netherlands
4 Department of Food Science and Nutrition, College of Sciences, Taif University, Taif 21944, Saudi Arabia

5 Department of Material Science and Technology, University of Ruse "A. Kanchev", 8 Studentska Str, 7017 Ruse, Bulgaria

6 Nano Technology Research Centre (NTRC), MCETRC, and Aarshanano Composite Technologies Pvt. Ltd, Guntur, Andhra Pradesh 522 201, India 